\title{
29. SEDIMENTARY AND VOLCANIC HISTORY: EAST MARIANA BASIN AND NAURU BASIN1
}

\author{
Seymour O. Schlanger, Department of Geological Sciences, Northwestern University \\ and \\ Ralph Moberly, Hawaii Institute of Geophysics²
}

\begin{abstract}
The sedimentary section recovered during Leg 89 at Deep Sea Drilling Project Site 525 provided a record of volcanism, plate motion, and other events of the Cretaceous and Cenozoic history of the East Mariana Basin. This part of the Pacific lithosphere had formed in the Jurassic; by late Aptian time it was at about $22^{\circ} \mathrm{S}$ and had subsided to a depth of about $5000 \mathrm{~m}$. In the Aptian and Albian, eruptions built major volcanic edifices nearby that were the sources of massive volcaniclastic debris flows and turbidites found at Site 525. The now deeply altered sediment originally was of quartz-normative tholeiitic basalt composition, with some later alkalic basalt contributions. Reefal debris, ooids, and displaced benthic foraminifers within the hyaloclastic and other volcanogenic components show that some of the volcanoes reached shallow water. They are now the seamounts and guyots north and south of the eastern end of the East Mariana Basin. Recovered cores show evidence of the Cenomanian-Turonian oceanic anoxic event in debris rich in organic carbon redeposited in turbidites, of passage under the equator in Campanian-Maestrichtian time from core paleomagnetism, and of the Oligocene (P21-P22) fall of sea level that exposed seamounts and thereby caused renewed turbidite activity.

The Nauru Basin igneous complex discovered during Leg 61 yielded cores of 12 additional volcanic units as a result of the deepening of Hole 462A during Leg 89. The mineralogical and geochemical homogeneity within these (and overlying) sheet flows, as well as their little-altered nature and small amount of interlayered sediment, indicate that the great volume of midplate magma was generated and erupted rapidly. The lowest flows drilled during Leg 89 probably are $130 \mathrm{Ma}$ (Valanginian). They lie on M26-aged ridge-crest crust (about $145 \mathrm{Ma}$, Oxfordian), and underlie volcanogenic sediment and sills representing at least two other episodes of midplate igneous activity, namely in the Aptian and Albian (about $100 \mathrm{Ma}$ ) and in the Campanian (about $75 \mathrm{Ma}$ ).
\end{abstract}

\section{INTRODUCTION}

The major drilling target for Leg 89 was the section of Cretaceous and Late Jurassic pelagic sediments presumed to overlie the Jurassic-age lithospheric basalt plate in the western Pacific. The JOIDES Ocean Paleoenvironment Panel had as one of its concerns during the decade of the 1970s recovery of cores of Mesozoic pelagic sediments in order to decipher the paleoceanography of the old Pacific superocean. Previous drilling in the area had revealed the presence of widespread and intensive Cretaceous volcanism; products of this volcanic activity in the form of widespread basalt flows, hyaloclastite sheets, and large edifices had either covered or destroyed the Early Cretaceous and Late Jurassic openocean pelagic record over wide areas of the western $\mathrm{Pa}$ cific. Following the discovery, on Leg 61 , of thick basalt flows of Early Cretaceous age in the Nauru Basin that thwarted efforts to penetrate the pelagic sediments thought to overlie the deeply buried lithospheric plate, new site surveys were commissioned to explore for drill sites in the Mariana Basin. Thus the basic plan for Leg 89 was to drill a multiple reentry hole in the East Mariana Basin to Jurassic sediments and, it was hoped, into the $\sim 145$-Ma plate. A secondary objective was to deepen Site 462 drilled on Leg 61 in the hope of penetrating the

\footnotetext{
${ }^{1}$ Moberly, R., Schlanger, S. O., et al., Init. Repts. DSDP, 89: Washington (U.S. Govt. Printing Office).

2 Addresses: (Schlanger) Dept. of Geological Sciences, Locy Hall, Northwestern University, Evanston, Illinois 60201; (Moberly) Hawaii Institute of Geophysics, University of Hawaii at Manoa, 2525 Correa Rd., Honolulu, HI.
}

flow complex found there. A third objective was to occupy Site 289 , drilled on Leg 30 , and by use of the relatively new hydraulic piston core obtain undisturbed samples of the pure carbonate pelagic sequence there to depths of approximately $300 \mathrm{~m}$. This drilling effort was assigned to Leg 89 in order to shorten the transit time for Leg 90 whose primary objective was to drill a northsouth transect from the Ontong-Java Plateau (Site 289) to the latitude of New Zealand as part of the JOIDES planning for Neogene paleoceanographic objectives. Results of this drilling are reported in both this volume and in the Leg 90 volume.

To these ends Glomar Challenger left Yokohama, Japan, shortly after midnight on 11 October 1982 and arrived at Noumea, New Caledonia, on the evening of 29 November.

Despite the fact that the Jurassic sedimentary objectives were not reached, Leg 89 did add to our knowledge of the timing and areal extent of the mid-Cretaceous volcanic events that have left their imprint over much of the western Pacific.

This chapter summarizes the sedimentary and volcanic history revealed by drilling in the East Mariana Basin at Site 585 (MZP-6 of the Leg prospectus); new data from the reoccupation of Site 462 (MZP-2 of the Leg prospectus) is included as it is relevant to that history. For additional details on results from the drilling on the OntongJava Plateau at Site 586 (SWP-9 of the Leg prospectus), readers are referred to the Leg 90 Initial Reports (Kennett, von der Borch et al., in press). Sites occupied on Leg 89 are shown in Figure 1. 


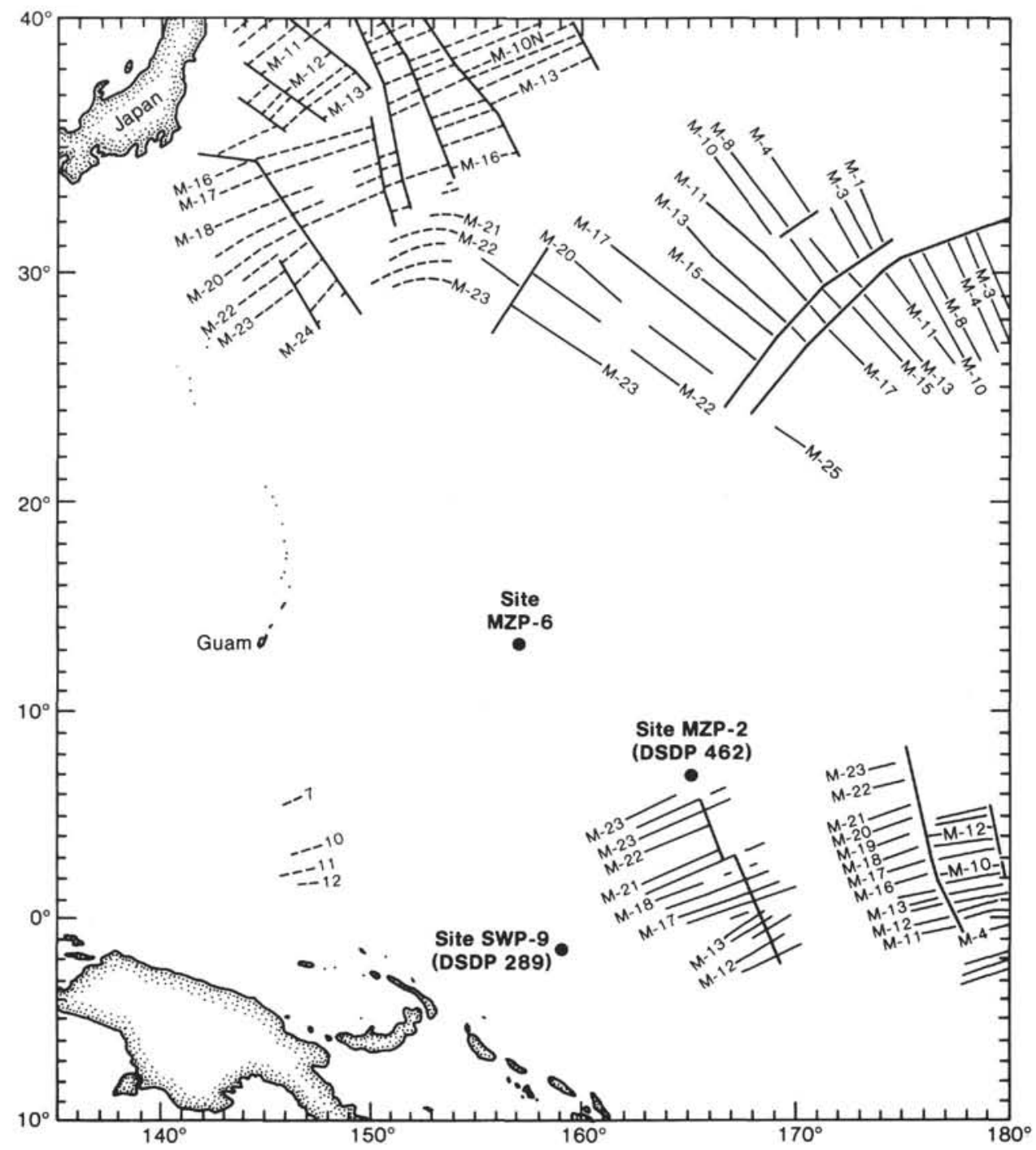

Figure 1. Magnetic lineations in the western Pacific in relation to proposed Leg 89 drilling Sites MZP-6 (Site 585), MZP-2 (a reentry at DSDP Site 462, Leg 61), and SWP-9 (a reoccupation and HPC drilling at DSDP Site 289, Leg 30).

\section{EAST MARIANA BASIN}

Site 585 (MZP-6) is located near the eastern end of the Mariana Basin, an elongate deep, surrounded in the east by submarine volcanic edifices of Cretaceous age (Fig. 2). The water depth in the Basin of $\sim 6100 \mathrm{~m}$ is in accord with the presumed plate age of Jurassic according to accepted subsidence curves for cooling lithosphere. The penetration of a thick sequence of Early Cretaceous volcanic flows in the Nauru Basin at Site 462 on Leg 89 appeared to confirm the argument that the anomalously shallow depth of the Nauru Basin could be ascribed to a Cretaceous thermal regeneration and uplift of the Nauru Basin that resulted in a resetting of the subsidence path (Larson and Schlanger, 1981). It was thought that because the Mariana Basin was at its predicted depth the influence of Cretaceous thermal resetting would be lacking there.

Previous drilling in the Mariana Basin took place on Leg 20 (see Heezen, MacGregor, et al., 1973) when Sites
199 and 200, 201, and 202 were drilled (Fig. 2); 200 and 201 are in close proximity to 202. At Site $199566 \mathrm{~m}$ of section was penetrated and spot-cored to a depth of $457 \mathrm{~m}$. The upper $209 \mathrm{~m}$ consisted of early Pliocene to middle Miocene turbidites made up of nannofossil ooze, brown silty zeolitic clay, and radiolarian ooze; this section was interpreted (Heezen, MacGregor, et al., 1973) as indicating that the Caroline Abyssal Plain existed as early as the middle Miocene. Below this section, to a depth of $447 \mathrm{~m}$, late Paleocene to early Maestrichtian nannofossil chalk, chert, and siliceous limestone were encountered; in the early Maestrichtian strata tuffs were common. The deepest core, at 447 to $457 \mathrm{~m}$, consisted of brown zeolitic tuff made up almost exclusively of glass shards. Heezen, MacGregor, et al. (1973) interpreted this tuff as a record of the final eruption of the volcanoes that formed the guyots that now lie along the eastern margin of the Caroline Abyssal Plain. Since the drilling of Leg 20, this Late Cretaceous volcanism has been recorded over large areas of the western Pacific (Schlanger 


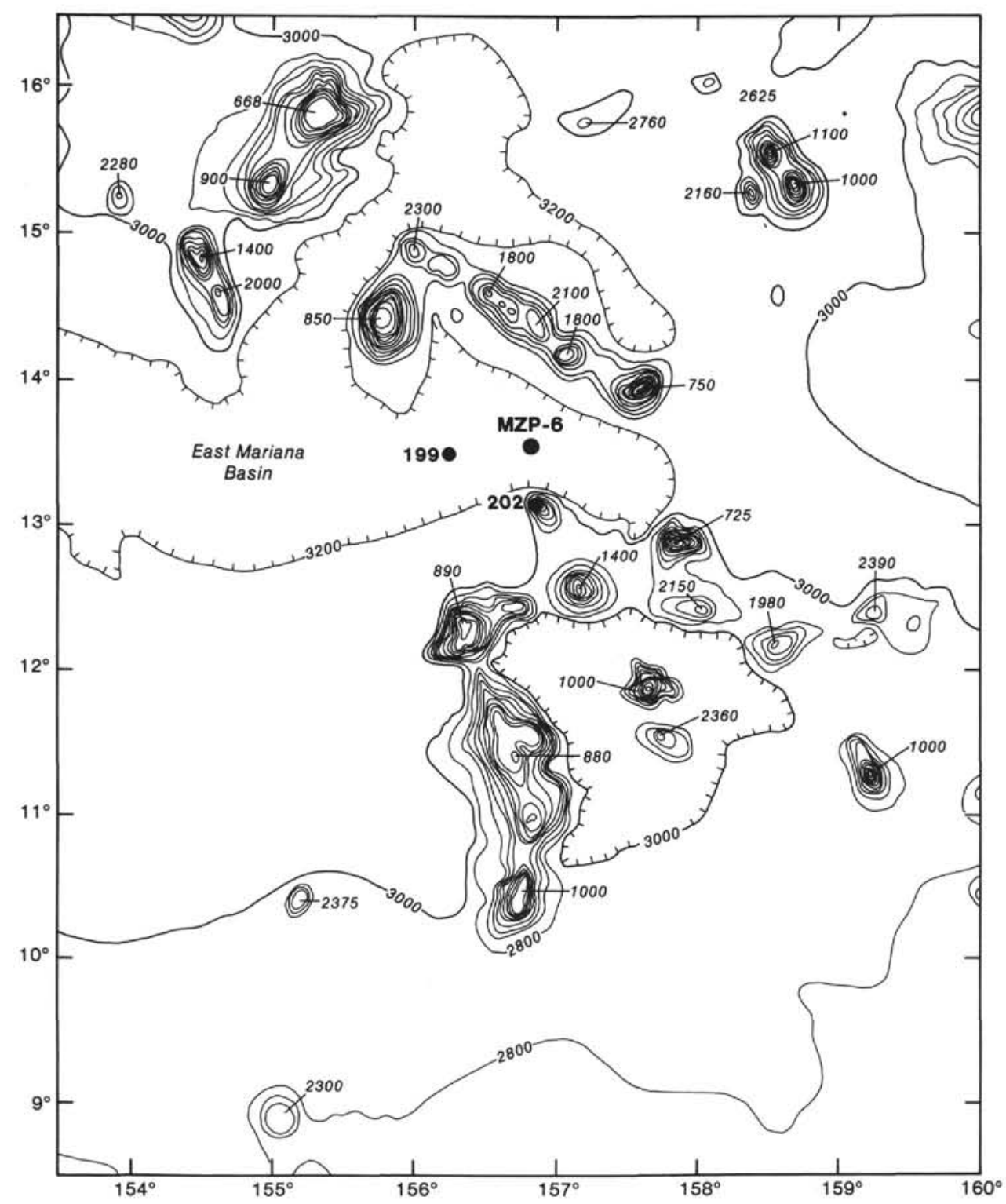

Figure 2. Bathymetric chart of the East Mariana Basin and surrounding seamounts showing the location of MZP-6 (Site 585, Leg 89). Drilling on Leg 20 (Heezen, MacGregor, et al., 1973) revealed Late Cretaceous pelagic sediments at Site 199 and shallow-water carbonate sediments atop Ita Maitai Guyot at Site 282 , which was presumed to be a Cretaceous volcanic edifice (bathymetry in fathoms after Chase et al., 1970).

and Premoli Silva, 1981). Sites 200, 201, and 202 of Leg 20 were drilled atop Ita Maitai Guyot (Fig. 4). At Sites 200 and 201 the drilling penetrated the acoustically determined pelagic cap of early Eocene to Quaternary Globigerina ooze; a few basalt fragments were found in the ooze. At Site 202, however, tan oolitic limestone was encountered at $100 \mathrm{~m}$ sub-bottom depth. Below the oolitic limestone were lime muds containing bryozoans and gastropods. The oolitic limestones and lime mud were interpreted as pre-early Eocene shallow-water materials deposited atop a Late Cretaceous volcanic edifice.

\section{Site Survey and Selection}

Although volcanism of both Early and Late Cretaceous age was revealed in the Nauru Basin on Leg 61
(Larson and Schlanger, 1981) and Late Cretaceous volcanism was recorded in the East Mariana Basin on Leg 20 (Heezen, MacGregor, et al., 1973), the depth of the Mariana Basin suggested that intensive Early Cretaceous volcanism had not occurred there. Therefore the East Mariana Basin was chosen for a site survey as shown in Figure 3 (see Shipley et al., 1983; Petersen et al., this volume).

Mapped magnetic lineations of the Mesozoic M-series (Fig. 3) indicated that MZP-6 was on old Pacific lithosphere that formed $\sim 145 \mathrm{Ma}$. The survey track crossed Site 199 on a course parallel to the east-west axis of the Mariana Basin (Fig. 4). Seismic profiles (Figs. 5 and 6) showed a thick sedimentary section along the axis of the basin, and Site MZP- 6 was chosen in the thickest part of 


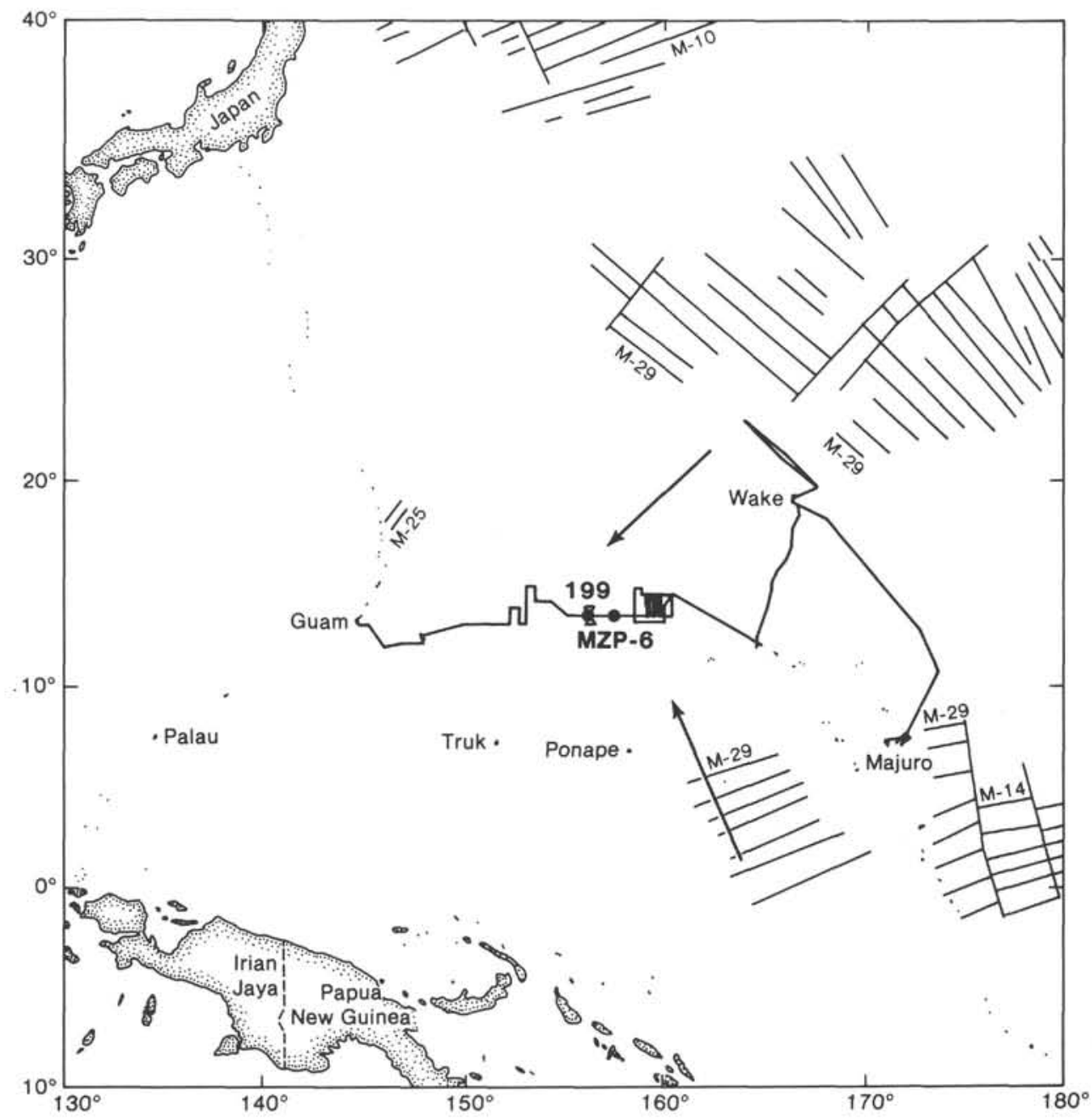

Figure 3. Site survey track of Kana Keoki KK810626 Leg 4 cruise. Large arrows point to the location of the presumably oldest crust in the Pacific basin (see Petersen et al., this volume).

the section. Interpretation of water gun profiles by the site survey team (Shipley et al., 1983; Petersen et al., this volume) are shown in Figure 6. From the seafloor to 590 $\mathrm{m}$ at $8.74 \mathrm{~s}$ two-way traveltime, the section at MZP-6 was taken to be equivalent to the section drilled at Site 199. Between 590 and $850 \mathrm{~m}$, that is, 8.74 to $9.0 \mathrm{~s}$ twoway traveltime, the section at MZP- 6 was predicted to be made up of biogenic pelagic sediments. From 850 to $1000 \mathrm{~m}$, down to the 9.1-s reflection, limestones deposited above the calcite compensation depth (CCD) were predicted to be lying directly above the Jurassic plate. The section from 850 to $1000 \mathrm{~m}$ sub-bottom depth was therefore considered the prime target for Leg 89 .

\section{Stratigraphic Section}

Two holes were drilled at Site 585. Although the JOIDES Planning Committee had approved the site as a reentry attempt, we were informed by DSDP engineers the day before departure that reentry would not be attempted because of the $\sim 6100-\mathrm{m}$ water depth at the site. At the site, weather conditions were good but calculations of dynamic stress on the drill string resulted in the final decision by the operations people to drill the site as a single bit hole. Hole 585 was terminated at $763.7 \mathrm{~m}$ T.D. due to a stuck misfit core barrel sub; a second attempt ended at $892.8 \mathrm{~m}$ upon total bit failure. The section drilled is summarized on Figure 7. As predicted by the site survey, the section down to approximately $490 \mathrm{~m}$ duplicated the section at Site 199. Between 490 and $590 \mathrm{~m}$ a section of middle Cenomanian through Santonian strata was drilled. Below $590 \mathrm{~m}$ to the total depth of 892.8 $\mathrm{m}$ the drilled section is markedly different from the section predicted by the site surveyors. Instead of Cretaceous and Jurassic pelagic carbonates, a thick section of late Aptian to middle Albian volcanogenic turbidites rich in ooids and shallow-water skeletal debris was found. The postdrilling correlation of seismic stratigraphy and lithology is shown on Figure 8.

\section{Sedimentology}

The sedimentary section recovered at Site 585 was divided into six lithologic units based on composition and degree of diagenesis and lithification (Fig. 7).

The highest unit is $6.8 \mathrm{~m}$ of lower Pleistocene to Recent brown clay and yellowish brown to brown clay-bear- 


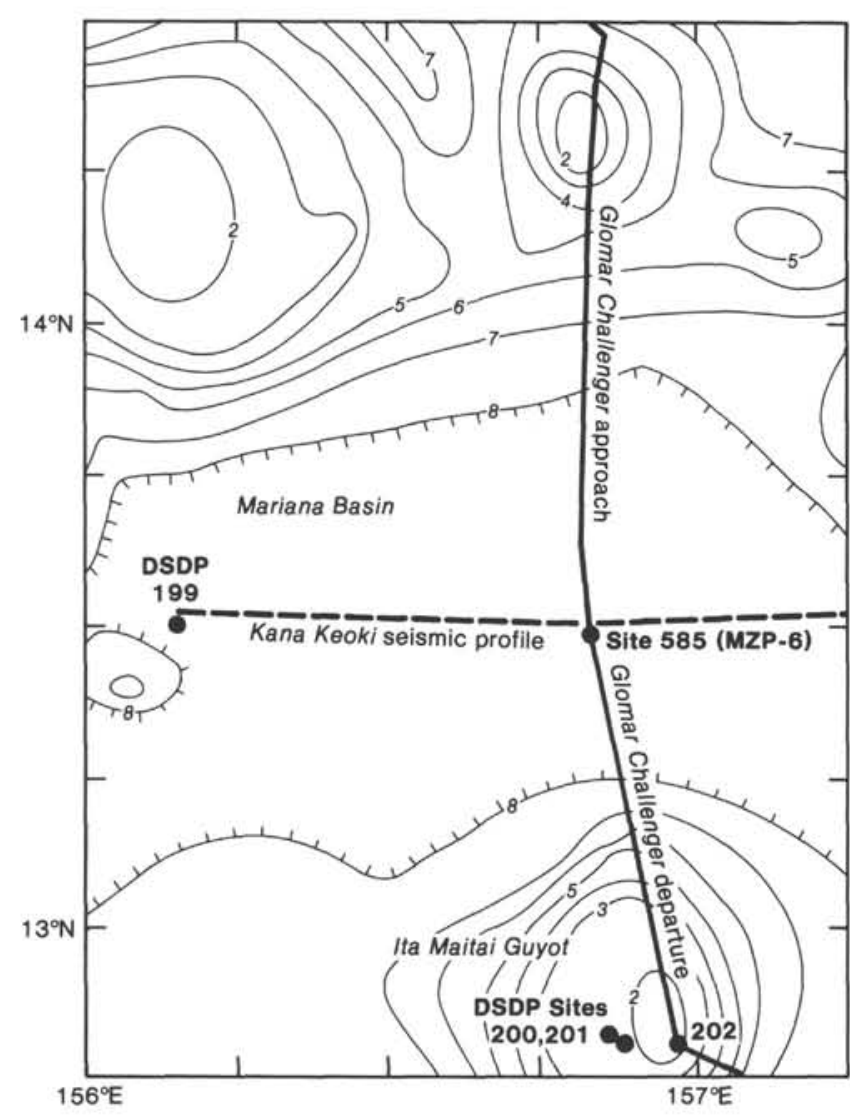

Figure 4. Glomar Challenger Leg 89 track across the East Mariana Basin. Bathymetry contoured in seconds of two-way traveltime from Petersen et al. (this volume), Chase et al., (1970), and Heezen, MacGregor, et al. (1973). One second is about $750 \mathrm{~m}$ depth; the abyssal plain of the Mariana Basin is slightly deeper than $6000 \mathrm{~m}$. ing nannofossil ooze. No cores were taken between 6.8 and $256 \mathrm{~m}$.

The next unit recovered is middle Eocene to Maestrichtian light gray, nannofossil chalk between 256 and $399 \mathrm{~m}$ sub-bottom depth. Varying amounts of limestone, silicified limestone, chert, and zeolitic clay indicate increased diagenesis with greater depth. The Appendix of the Site 585 report shows the composition changes graphically; they are described by Baltuck (this volume).

From 399 to $426 \mathrm{~m}$ sub-bottom depth the section is Maestrichtian to upper Campanian dark brown zeolitic claystone of variable carbonate content. These beds, many of which show subtle grading, lie on Campanian chert interbedded with brown zeolite-bearing claystone $(426-485 \mathrm{~m})$. The silicification, which commonly is replacement of pore filling of limestone, is complex (Baltuck, this volume).

From 485 to $590 \mathrm{~m}$ sub-bottom depth the section is Campanian to middle Albian claystone with variable amount of zeolite, carbonate, and radiolarians. Special attention was given to description and interpretation of the turbidite sequences (Whitman et al., this volume), secondary silicate minerals (Chamley et al., this volume), and organic geochemistry (Schaefer and Leythaeuser, this volume).

A thick section of volcaniclastic sediments lies below $590 \mathrm{~m}$, extending at least to the total depth of $893 \mathrm{~m}$ sub-bottom. These middle Albian to upper Aptian sandstones, siltstones, claystones, and breccias were explained as turbidites and debris flows (Whitman et al., this volume), from volcanic edifices (Floyd, this volume; Viereck et al., this volume), some of which were sufficiently shallow to provide the mainly hyaloclastic debris with ooid and reefal admixtures (Haggerty and Premoli Sil$\mathrm{va}$, this volume).

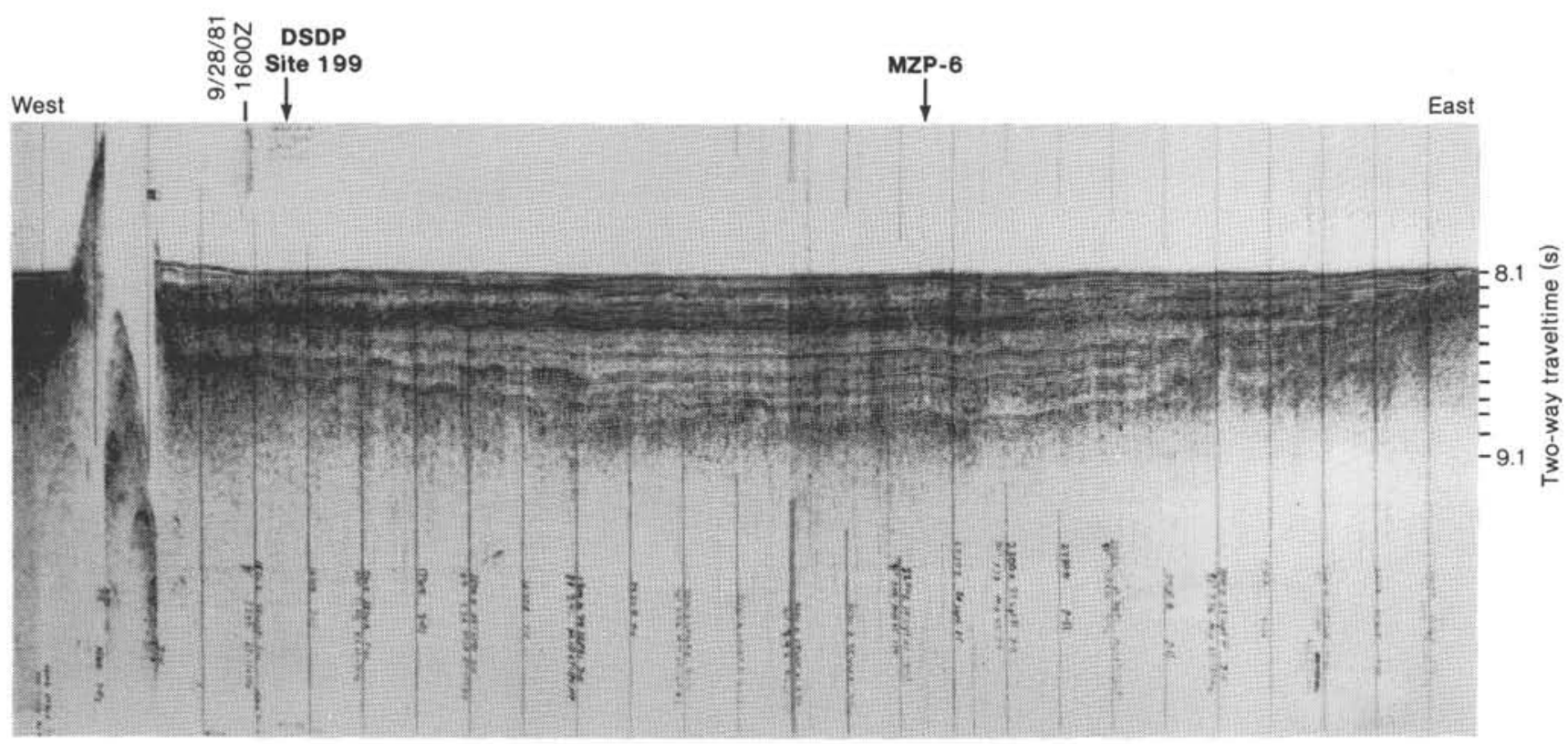

Figure 5. Seismic profile along Kana Keoki track shown in Figure 4. 


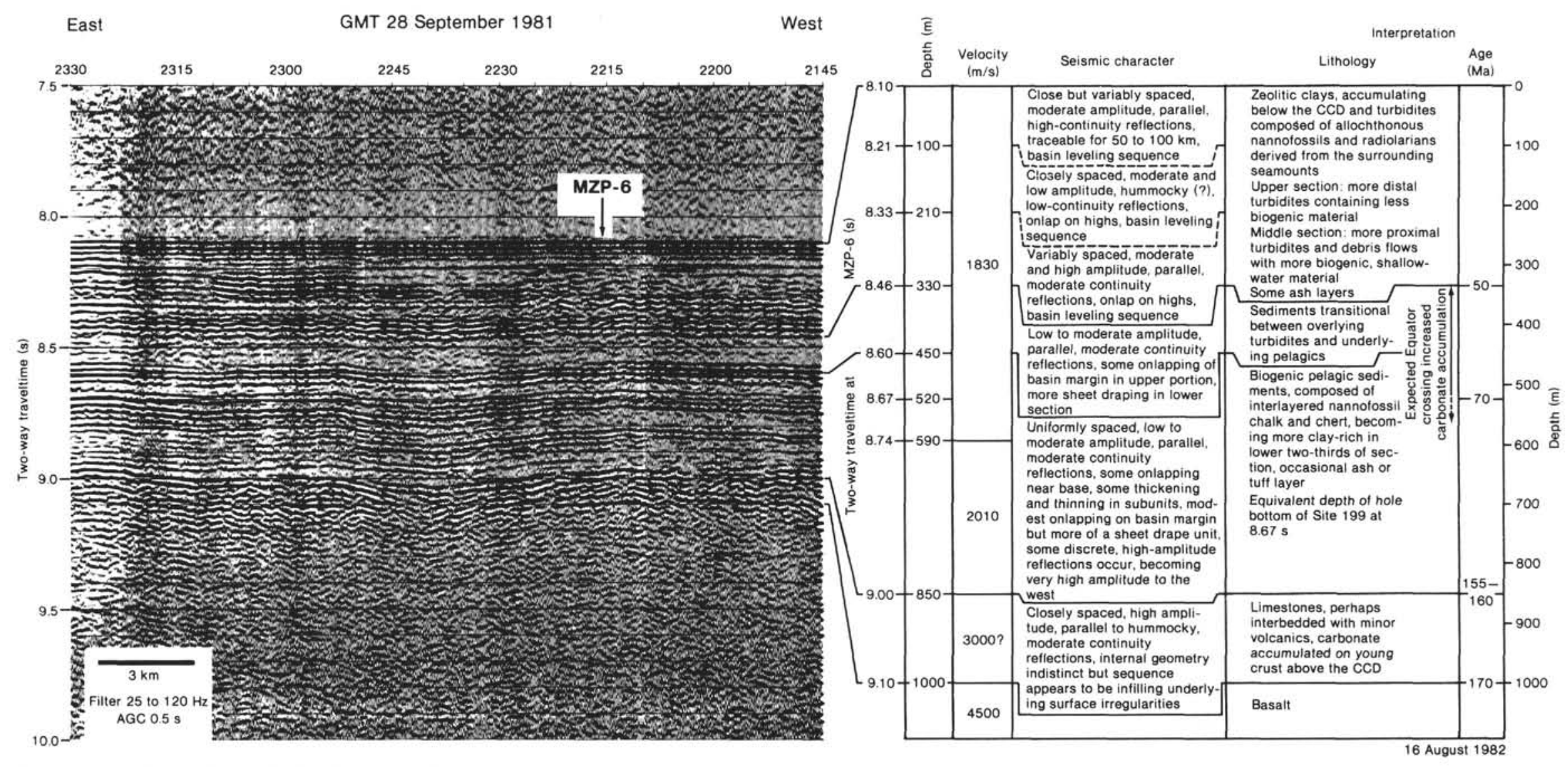

Figure 6. Seismic reflection section in the East Mariana Basin across proposed Site MZP-6 (Site 585). The interpretations of the section in terms of depth to reflector, interval velocities, seismic character, and lithology were made prior to drilling at Site 585 (from Shipley et al., 1983). See also Whitman (this volume). 


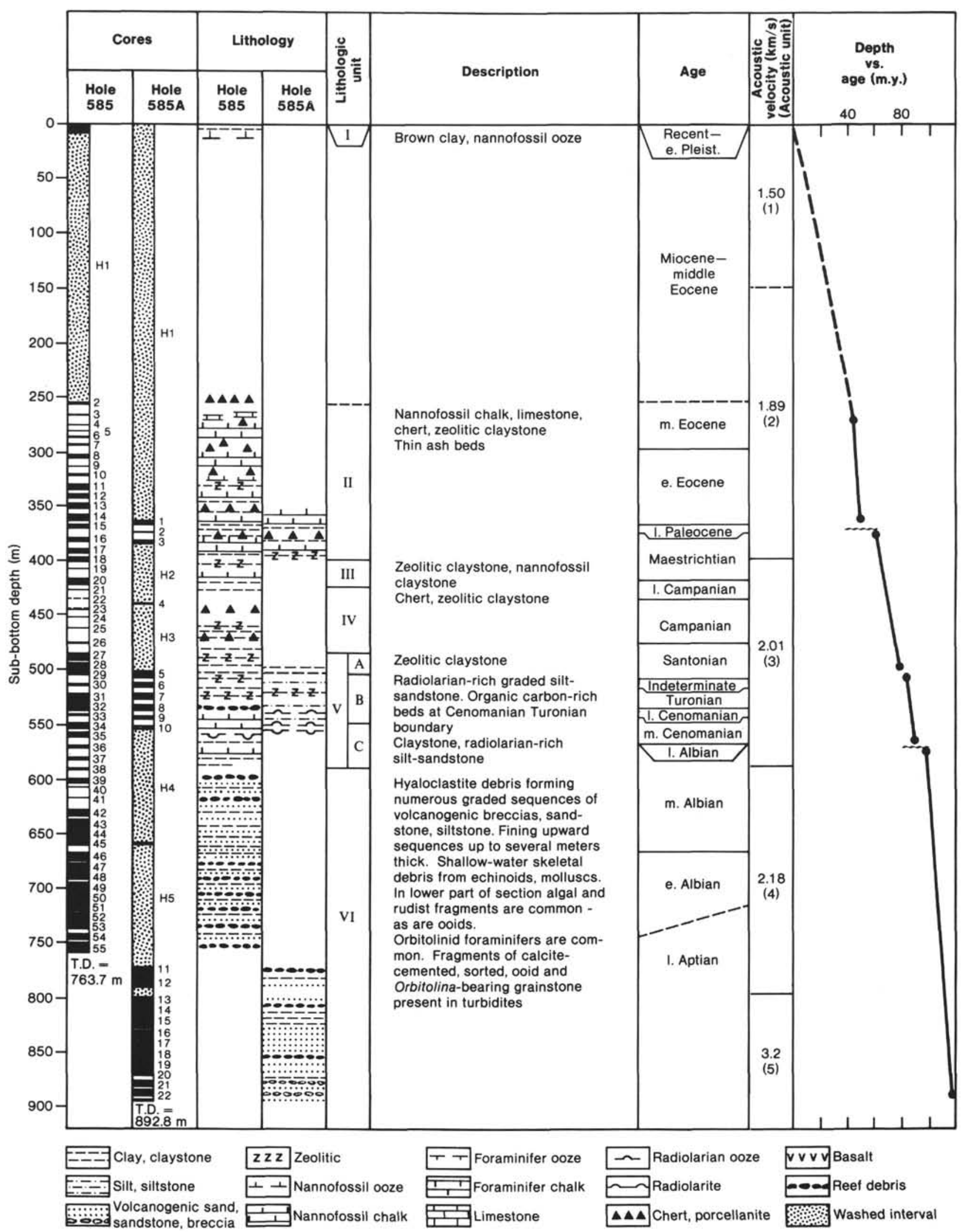

Figure 7. Drilling results from Holes 585 and 585A, Site 585, East Mariana Basin. (Details are given in the Site 585 report, this volume.) 


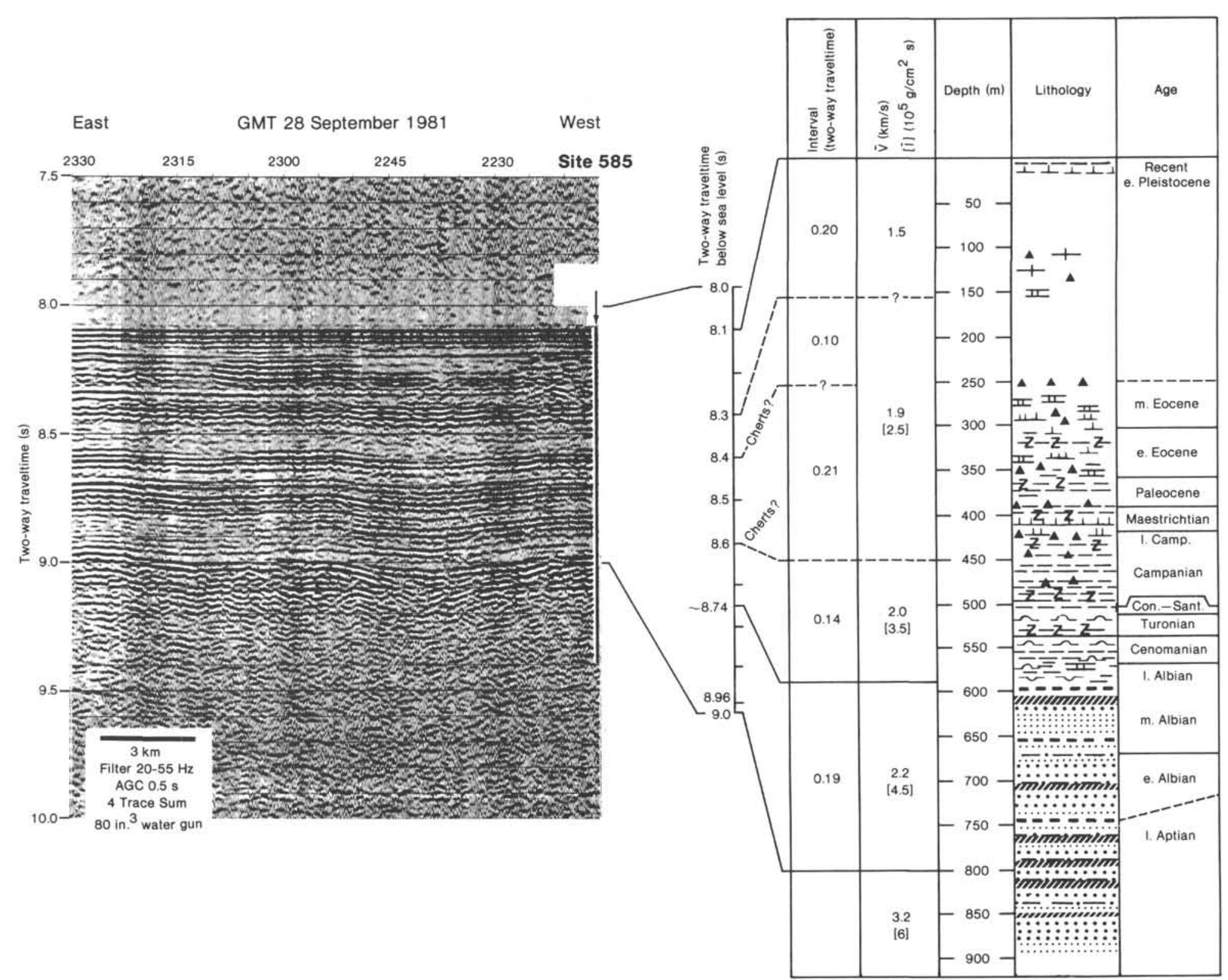

Figure 8. Seismic profile at Site 585 interpreted in terms of drilling results from Holes 585 and 585A. See Figure 6 in order to compare predrilling and postdrilling interpretations. 


\section{History of Plate Motions}

\section{Paleolatitude from Paleomagnetism}

Paleolatitude data derived from Holes 585 and 585A can be interpreted as indicating a steady northward motion of the Pacific plate underlying the East Mariana Basin at a rate of $32.5 \mathrm{~km} / \mathrm{yr}$. from late Aptian through Paleocene time (Ogg, this volume). The paleolatitude data sets from the two holes coincide very well and display no systematic offset from each other. This coincidence reinforces the reliability of the computed paleolatitude curve shown on Figure 9.

Three clusters of Cretaceous paleolatitude determinations can be differentiated (Fig. 9): (1) a PaleoceneMaestrichtian group centered at about $1^{\circ} \mathrm{S}$ latitude, (2) a Santonian-Turonian (plus some Campanian and Cenomanian) cluster centered at about $7^{\circ} \mathrm{S}$ latitude, and (3) an Albian-late Aptian cluster centered at $15^{\circ} \mathrm{S}$ latitude. There was inadequate recovery of sediments and paleomagnetic sampling at Site 585 to derive reliable pa-

$\mathrm{Ma}$

(time scale of Harland et al., 1982)

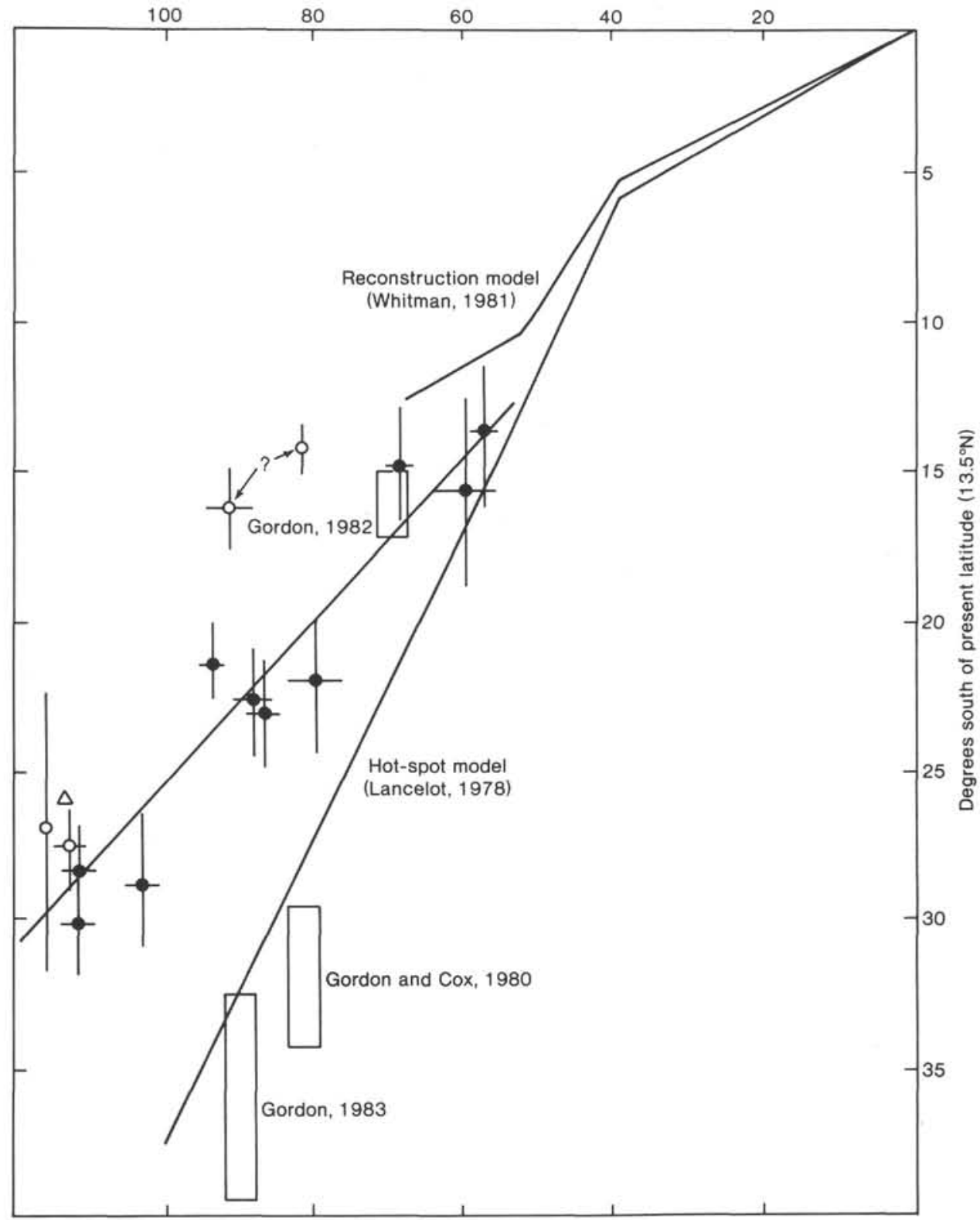

Figure 9. The amount of northward drift of the western Pacific, as computed from the paleolatitudes of Sites 585 (solid dots), 462 (open dots), and 289 (open triangle), relative to the present latitude of those sites. For comparison, the predicted amounts of northward drift for the location of Site 585 from the Pacific poles (boxes), computed by Gordon (1982), Gordon and Cox (1980), and Gordon (1983), from the hot-spot model of Lancelot (1978), and from the reconstruction model of Whitman (1981) are also plotted (from Ogg, this volume). 
leolatitudes for the Campanian or Cenomanian or for the Tertiary. Therefore, whether the site had a constant northward drift during the Cretaceous or underwent episodes of rapid movement between relative standstills cannot be determined. An average northward drift rate of $32.5 \mathrm{~km} / \mathrm{m}$.y. (3.25 cm/yr.) is shown as an approximate fit to the three clusters. This average Cretaceous value is less than the $50 \mathrm{~km} / \mathrm{m}$.y. predicted by the Pacific hotspot model of Lancelot (1978) and greater than the rates predicted for the latest Cretaceous and early Tertiary by Whitman's model (1981), which uses global reconstructions on magnetic anomalies.

Several paleomagnetic poles have been computed for the Pacific plate by combining data sets from DSDP sites, from modeling of seamount magnetism, and from skewness of marine magnetic anomalies. Gordon (1982) computed a late Maestrichtian ( $\sim 69 \mathrm{Ma})$ paleomagnetic pole for the Pacific plate as $71^{\circ} \mathrm{N}, 9^{\circ} \mathrm{E}$, which would predict a paleolatitude for Site 585 at $2.7^{\circ} \mathrm{S}(95 \%$ confidence level of $2^{\circ}$ ). This paleolatitude compares excellently with the line-fit value for Site 585 of $3^{\circ} \mathrm{S}$.

Gordon and Cox (1980) computed an average Campanian ( $81 \mathrm{Ma}$; chron 33R) paleomagnetic pole for the $\mathrm{Pa}$ cific plate at $56.6^{\circ} \mathrm{N}, 353.5^{\circ} \mathrm{F}$, which would predict a paleolatitude of $18.6^{\circ} \mathrm{S}\left(95 \%\right.$ confidence level $\left.=4^{\circ}\right)$ for Site 585 . The actual paleolatitude is $6.5^{\circ} \mathrm{S}$ using the 81-Ma intersection of the line fit to the data, or up to $8.5^{\circ} \mathrm{S} \pm 2.2^{\circ}$ if the average Campanian-Santonian value of Hole 585 is used. Therefore Site 585 was $12^{\circ}$ farther north than predicted by the pole of Gordon and Cox (1980). A Pacific paleomagnetic pole for $90 \mathrm{Ma}$ was computed by Gordon (1983) to be at $54^{\circ} \mathrm{N}, 334^{\circ} \mathrm{E}$, which would predict a paleolatitude for Site 585 of $22.5^{\circ}(95 \%$ confidence level $=6^{\circ}$ ). The actual value is tightly constrained to be $9^{\circ} \mathrm{S}\left( \pm 2.5^{\circ}\right)$. Therefore the site was about $13.5^{\circ}$ farther north than predicted by the pole of Gordon.

It is beyond the scope of this chapter to attempt to resolve the differences between the predictions of the Late Cretaceous Pacific poles by Gordon (1983) and Gordon and Cox (1980) and the actual paleolatitudes of Site 585. It is interesting that the amount of change in paleolatitudes agrees well with the Late Cretaceous results from Site 462 in the nearby Nauru Basin (Steiner, 1981a, b). Perhaps the western Central Pacific Basin had differential movement from the North Pacific Basin and eastern Central Pacific Basin (where Gordon's poles are derived) during the Late Cretaceous. The predictions agree with the actual paleolatitude of Site 585 in the Maestrichtian, therefore such a theoretical displacement would have been completed by that stage. The spurt of rapid northward motion of the Pacific plate during the mid-Late Cretaceous proposed by Gordon (1983) is not apparent in the data from Site 585 or Site 462 . Instead, a fairly constant northward drift component of about $23.5 \mathrm{~km} / \mathrm{m}$.y. would fit the late Aptian through early Tertiary results.

\section{Paleobathymetry from Paleontology}

Cretaceous benthic foraminifers from Site 585 in the Mariana Basin, western Pacific Ocean, provide an environmental, paleobathymetric, and tectonic history of the
Basin and the surrounding seamounts (see Sliter, this volume). Age-diagnostic species that are contained in the turbidite fill of the Mariana Basin range from late Aptian to Maestrichtian in age. Displaced species in sediments derived from the tops and flanks of nearby seamounts were deposited sporadically on the Basin floor well below the CCD at abyssal depths of 5000 to $6000 \mathrm{~m}$. These abyssal depths, characterized by an indigenous assemblage of benthic foraminifers, recrystallized radiolarians, fish debris, and sponge spicules, existed in the Mariana Basin from late Aptian to the present. Early Albian and older edifice-building volcanism had reached the photic zone and shallow-water bank or reef environments existed atop seamounts. The ooids and shallowwater foraminifers deposited from Ita Maitai Guyot can be now considered as Albian-Aptian in age. By middle Albian, the dominant source areas subsided to outerneritic to upper-bathyal depths. Major volcanic activity ceased and fine-grained sediments were deposited by distal turbidites, although intermittent volcanism and the influx of rare neritic material continued until the late Albian. By the Cenomanian to Turonian, upper- to middle-bathyal depths were reached by the dominant source areas, and the sediments recovered from this interval include organic, carbon-rich layers. Rare benthic foraminifers from the Coniacian-Santonian interval indicate a continuation of dominantly middle-bathyal source areas. A change in sedimentation during the Campanian-Maestrichtian from older zeolitic claystone in the Maestrichtian resulted from migration of the site beneath the equatorial productive zone due to northwestward plate motion. The appearance of rare middle-neritic and upper bathyal species in the Maestrichtian interval associated with volcanogenic debris gives evidence of the remobilization and downslope transport of pelagic deposits as a result of renewed Late Cretaceous volcanism in the area.

\section{Subsidence History of the East Mariana Basin}

Based on the assumption that the Pacific plate lithosphere below the East Mariana Basin could be as old as $\sim 170 \mathrm{Ma}$ (Whitman et al., this volume), the subsidence history can be modelled by taking into account thermal subsidence and isostatic effect of loading by sediments. Figure 10 shows a subsidence curve for the basement in this region of the Basin with the subsidence history of the sedimentary section superimposed. The backtracking of horizons is based on sedimentation rates, the thickness and density of the rocks in the lithologic units, and the age versus depth equation of Parsons and Sclater (1977). No corrections were made for compaction and density changes through time. This technique yields an estimate for the Mesozoic ridge-crest depth of $3110 \mathrm{~m}$.

Our ridge-crest depth predicted by Whitman et al. (this volume) is significantly deeper than present ridge-crest depths. Although this prediction supports $170 \mathrm{Ma}$ as a minimum age estimate for crust in this region, it raises questions about the origin of the crust and its history since formation. If the sedimentary sections extend to $9.5 \mathrm{~s}$, an initial ridge-crest depth of almost $3400 \mathrm{~m}$ is indicated, further emphasizing that the subsidence history of this Basin has been very different from other areas of 


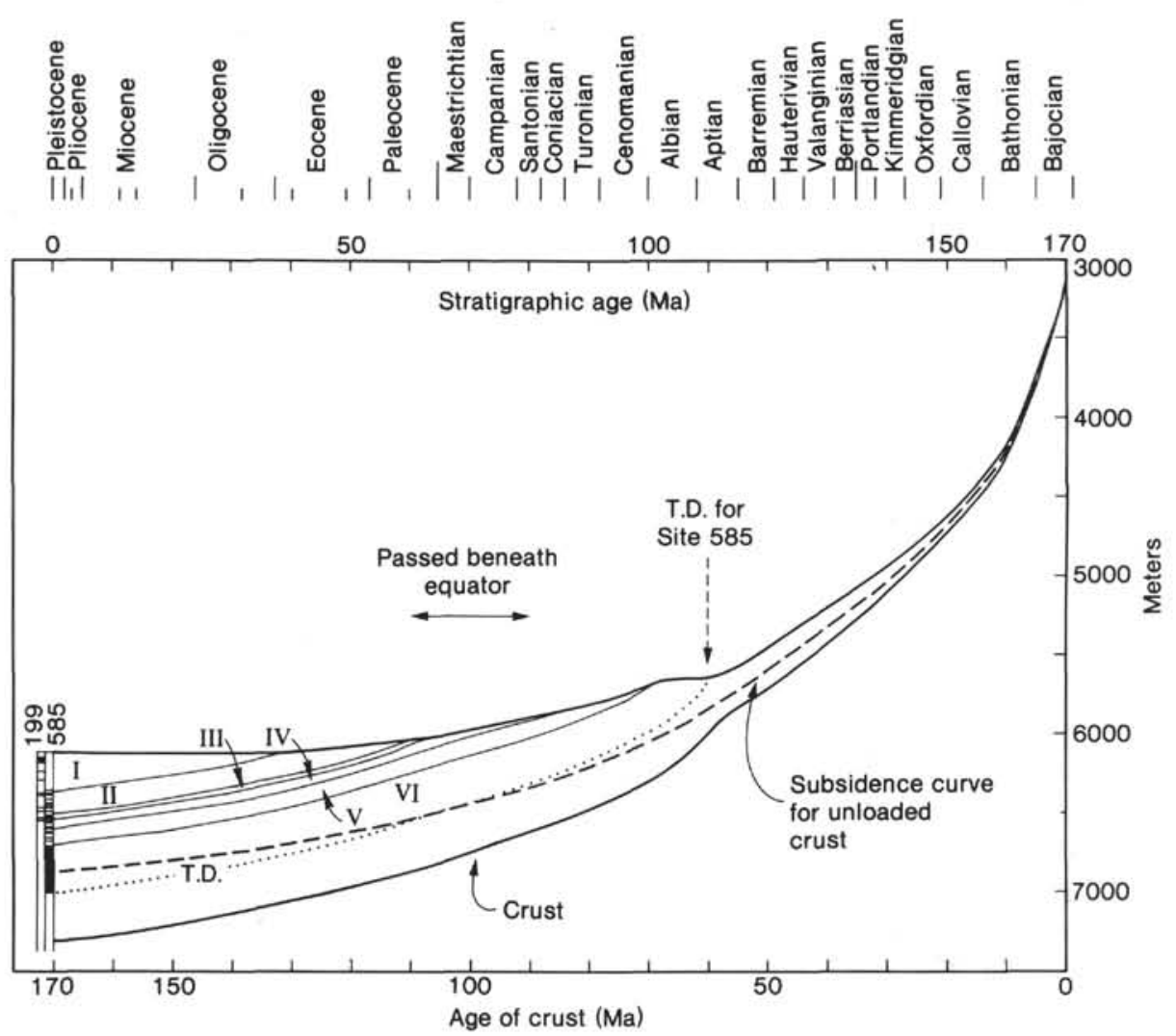

Figure 10. Backtracking curve of the Mariana Basin near Sites 199 and 585 . Lithologic units recovered at Site 585 (I-VI), total depth (T.D.) for Site 585, and subsidence curve for 170-m.y.-old unloaded crusts are indicated. Thermal subsidence (Parsons and Sclater, 1977) and isostatic correction for sediment loading have been applied. Time scale is based on Hardenbohl and Berggren (1978), Berggren and van Couvering (1974), and van Hinte (1976a, b).

the oceans, beginning with creation at an anomalously deep spreading center.

Anomalously shallow depths in the Pacific have been attributed to many causes (see Schlanger, in press, for review), including the thermal effects of widespread midplate volcanism during the Late Cretaceous (155-70 Ma) in the Nauru Basin (Schlanger et al., 1981), the emplacement of sills within the sedimentary section of the Nauru Basin during the Late Cretaceous (Larson and Schlanger, 1981), the formation of "asthenospheric bumps" caused by the patterns of convection cells (Menard, 1973), arches formed in crustal deformation due to the load of oceanic volcanoes (Menard, 1964; McNutt and Menard, 1978), and crustal thinning produced by heating from an underlying hot spot (Detrick and Crough, 1978; Crough, 1978).

Anomalies of excessive depth have received very little treatment by previous authors. Because the Mariana Basin is anomalously deep, it cannot have undergone the reheating that affected other areas of the western Pacific, but instead it raises the question of whether the converse, excessive cooling, occurred in the area of this Basin. Parsons and Sclater (1977) found that the age versus depth relationship deviates from a linear square root of age $\left(\mathrm{t}^{1 / 2}\right)$ model for oceanic crust older than $70 \mathrm{~m} . \mathrm{y}$. They proposed that heating at the bottom of the lithosphere maintains a constant plate thickness and causes the sub- sidence curve to flatten out and approach an asymptotic value for older crust. To resolve this problem, they proposed an exponential relationship between age and depth for crust older than 70 m.y. Our subsidence curve (Fig. $10)$ has been produced using the two separate equations they proposed.

Calculations by Whitman et al. (this volume), however, for the depth to crust at 170 m.y., isostatically corrected for sediments, falls very close to a curve of $\mathrm{t}^{1 / 2}$. If the crust at this site has followed only the linear $t^{1 / 2}$ relationship, it implies that the lithosphere beneath this Basin has not received additional heating to maintain a plate of constant thickness and that the plate has continued to thicken beyond the maximum value of $125 \mathrm{~km}$ suggested by Parsons and Sclater (1977). Pollack et al. (1981) have contoured the thickness of the lithosphere, and the western Pacific is a region of greater thickness than most of the ocean basins, but their resolution is not good enough to prove or disprove the theory at this point. Whitman et al. (this volume) offer the hypothesis that the crust of the Mariana Basin is above a "cold spot," receiving less heating by the mantle, producing a thickened lithosphere and excess subsidence.

\section{Summary of Plate History}

Taking the paleolatitude analysis of Ogg (this volume), the paleobathymetric interpretations of Sliter (this vol- 
ume), and the subsidence history of Whitman et al. (this volume) as discussed above into account, the following history of the evolution of the East Mariana Basin can be proposed. After formation of the plate at a ridge crest in Jurassic time, this basement reached a paleolatitude of $22^{\circ} \mathrm{S}$ in late Aptian time. At this point the Basin was at a depth of from 5000 to 6000 m. In Aptian-Albian time major volcanic edifices grew up to sea level and provided the source of much of the volcanogenic and bioclastic turbidite debris. These edifices then subsided as the plate moved northward and crossed the equator in Campanian-Maestrichtian time. Further volcanic activity took place in the region, but subsidence continued as the Basin moved northward to its present position at $13.5^{\circ} \mathrm{N}$.

\section{The Cenomanian-Turonian Oceanic Anoxic Event in the Mariana Basin}

One of the objectives of Leg 89 was to seek evidence, in the Cretaceous strata to be drilled, for the occurrence of the Cenomanian-Turonian oceanic anoxic event in the western Pacific. Based on earlier DSDP results and a study of outcrops, Schlanger and Jenkyns (1976) had postulated the occurrence of oceanic anoxic events (OAE) during stratigraphically restricted intervals. During these events strata containing significant amounts of organic carbon were deposited within an expanded $\mathrm{O}_{2}$ minimum zone in the global ocean (see also Arthur and Schlanger, 1979; Jenkyns, 1980). One of these OAE's took place at, or very close to, the Cenomanian/Turonian boundary. Stratigraphic sequences of late Cenomanian and early Turonian age that contain organic carbon-rich "black shales" have been described throughout the Tethys, the Atlantic Basin, in European shelf settings, in African marginal basins, or plateaus in the Pacific and in the U.S. Western Interior Basin (Schlanger et al., in press).

In both Holes 585 and $585 \mathrm{~A}$ thin beds rich in kerogen of marine algal origin were cored. In Section 585-32-3, a 2-cm-thick band of black, pyritic, silty claystone was recovered (see fig. 15, Site 585 report; and Frontispiece, this volume). Shipboard analysis of $\mathrm{C}_{\mathrm{org}}$ in samples from this band showed values of $5.6 \%$ and $5.1 \%$; reanalysis ashore (see Site 585 report; and Schaefer, this volume) showed a $\mathrm{C}_{\text {org }}$ value of $9.9 \%$. A high hydrogen index of $383 \mathrm{mg} / \mathrm{g} \mathrm{C}_{\mathrm{org}}$ reflects the high content of both dinoflagellates and unicellular marine algae. The Cenomanian/ Turonian boundary is placed within Core 585-32 with the latest Cenomanian faunal assemblage occurring in Core 585-34. Thus this $\mathrm{C}_{\text {org }}$-rich black band is within a meter or two of the Cenomanian/Turonian boundary. In Core $585 \mathrm{~A}-8, \mathrm{CC}$ a thin lamina of $\mathrm{C}_{\text {org }}$ and radiolarian-rich sediment contains $1.45 \% \mathrm{C}_{\text {org }}$ according to shipboard analysis and $2.6 \%$ according to shore lab analyses. The $\mathrm{C}_{\text {org }}$ is made up of immature, marine algal-derived carbon. The Cenomanian/Turonian boundary in Hole $585 \mathrm{~A}$ is placed at the level of Core $585 \mathrm{~A}-9 \sim 50 \mathrm{~cm}$ below the black lamina.

The presence of these $\mathrm{C}_{\text {org }}$-rich layers at, or very close to, the Cenomanian/Turonian boundary, their content of marine-derived $\mathrm{C}_{\text {org }}$, and the lack of any other $\mathrm{C}_{\text {org }}$ rich layers above or below the Cenomanian/Turonian boundary argue for the interpretation that these $\mathrm{C}_{\mathrm{org}}$ rich layers are manifestations of the Cenomanian-Turonian OAE. However, as it can be clearly seen in figure 15 of the Site 585 report (this volume), these bands are in turbidite sequences. Further, benthic foraminifers from above and below the $\mathrm{C}_{\text {org }}$-rich layer in Section 585-32-3 consist of species most representative of upper to middle bathyal environments mixed with rare elements of the indigenous deep abyssal assemblage (Sliter, this volume). Also, extensive bioturbation in the late Cenomanianearly Turonian section shows that the deep bottom waters were oxygenated. It seems clear then that these $\mathrm{C}_{\text {org }}{ }^{-}$ rich bands were redeposited from the flank of the surrounding seamounts, the slopes of which were within an $\mathrm{O}_{2}$-minimum zone during Cenomanian/Turonian boundary time (Whitman et al., this volume). The stratigraphically restricted occurrence of the $C_{\text {org }}$ layer in the East Mariana Basin argues for the interpretation put forward by Schlanger and Jenkyns (1976) that a short-lived global expansion of the $\mathrm{O}_{2}$-minimum zone took place at the Cenomanian/Turonian boundary and that this new East Mariana Basin data fit the global picture of the ubiquity of $\mathrm{C}_{\text {org }}$-rich black bands at this stratigraphic horizon (Schlanger et al., in press; Arthur et al., in press).

\section{Oligocene Sea Level Falls Recorded by Turbidite Events}

DSDP sites in the Line Islands and Marshall Islands atoll provinces were selected, among other reasons, to study the stratigraphy of the deep-water archipelagic aprons around the atolls. The assumption was that turbidite beds made up of fossil skeletal debris eroded from the nearby atolls and associated shallow banks would record the history of atoll development including periods of emergence (Winterer, Ewing, et al., 1973; Schlanger, Jackson, et al., 1976; Larson, Schlanger, et al., 1981). At DSDP Site 462 drilled on Leg 61 in the Nauru Basin and at Sites 165 and 315 in the Line Islands drilled on Legs 17 and 33, distinct coarse-grained, graded turbidite units made up of tests of age-diagnostic large benthic foraminifers, and fragments of calcareous algae, bryozoans, mollusks, and echinoids of reefal and shallowbank origin were cored and were found to be restricted to Late Cretaceous, Oligocene, middle Miocene, and Pliocene-Pleistocene stratigraphic intervals (Premoli Silva and Brusa, 1981; Schlanger and Premoli Silva, 1981). Premoli Silva (this volume) has revised the stratigraphic ages assigned to these turbidite horizons. In the Leg 61 report Premoli Silva and Brusa reported that the erosional events that produced the turbidites took place at $37 \mathrm{Ma}, 32 \mathrm{Ma}, 26 \mathrm{Ma}$, and $13 \mathrm{Ma}$ (1981). The events are now dated (Premoli Silva, this volume) at $30 \mathrm{Ma}, 28$ $\mathrm{Ma}, 26 \mathrm{Ma}$ or younger, and $12 \mathrm{Ma}$, respectively. The following section is summarized from Schlanger and Premoli Silva (in press).

The data and interpretations presented here are from a midplate setting in the central Pacific, a region where subsidence rates are well-constrained and atolls and associated sediments contain records of relative sea level changes. The interpretations of seismic stratigraphic sections of passive margins argue for the occurrence of a 
major coastal offlap event and an inferred global sea level fall at $30 \mathrm{Ma}$ (Vail et al., 1977) or $29 \mathrm{Ma}$ (Vail and Hardenbohl, 1979), correlative with the planktonic foraminiferal Zone P21 (Globorotalia opima opima), with lesser falls at 22 and $24 \mathrm{Ma}$ (Vail and Hardenbohl, 1979). Stratigraphic studies of exploratory wells on the New Jersey margin and DSDP sites on the Goban Spur of the Irish continental margin have defined a series of Oligocene offlap events that produced stratigraphic hiatuses in the shelf sequences (Poag, 1980; Olsson et al. 1980; Graciansky et al., 1984; Miller et al., 1984; Miller et al., 1985). Miller et al. (1985) correlated increases in $\delta^{18} \mathrm{O}$ values from $\sim 1.5 \%$ to $\sim 2.0 \%$ (Miller et al, . 1985; Keigwin and Keller, 1984; Savin et al., 1975; Boersma and Shackleton, 1977), taken as indicative of glacial buildups, with these hiatuses and inferred three Oligocene glacio-eustatic sea level falls: a minor fall at approximately $36 \mathrm{Ma}$, and major falls with significant offlaps at $31 \mathrm{Ma}$ in the P21 Zone (G. opima opima) and $25 \mathrm{Ma}$ in the P22 Zone (Globigerina ciperoensis). Because all of this work is based on stratigraphic sections deposited in passive margin tectonic settings and the exact relationship between global glacio-eustatic sea level swings, offlap events, and margin subsidence history are not completely determined, it is important that evidence for Oligocene sea level falls be sought in other tectonic settings such as the mid-Pacific.

The turbidites drilled in the Marshall and Line islands provinces contain several distinct foraminiferal assemblages of Cretaceous through late Oligocene age and lie enclosed in archipelagic carbonates of mid-Oligocene age in the P21 (Globorotalia opima opima) Zone of late Oligocene age in the P22 (Globigerina ciperoensis) Zone. We propose here that these Oligocene turbidites were deposited during sea level falls and that they are correlative with the two major passive margin offlap events described by Miller et al. (1985). Miller et al. (1985) correlate three $\delta^{18} \mathrm{O}$ events, taken to indicate the development of significant glaciation, with offlap events and glacioeustatic sea level falls that caused the development of hiatuses in the stratigraphic sections drilled on the New Jersey and Irish (Goban Spur) passive margins. These workers recognized that in passive margin settings erosion and offlap should occur during times of maximum rate of eustatic sea level fall that they date as about 36 $\mathrm{Ma}$ (latest Eocene to Eocene/Oligocene boundary), about $31 \mathrm{Ma}$ in the P21 Zone, and about $25 \mathrm{Ma}$ (late Oligocene). The turbidites at both DSDP Sites 462 and 315 in the P21 Zone correlate with the most marked Oligocene hiatus in both the New Jersey and Irish continental margins and the related $\delta^{18} \mathrm{O}$, offlap, and maximum rate of sea level lowering events. The turbidites at DSDP Sites 462,315 , and 165 that lie in the P22 Zone correlate with the late Oligocene hiatus and the related $\delta^{18} \mathrm{O}$, offlap, and maximum rate of sea level lowering events described by Miller et al. (1985). The approximately $36 \mathrm{Ma} \delta^{18} \mathrm{O}$ and sea level lowering event seen on the passive margins, however, is not clearly recorded in the mid-Pacific sections.

Further evidence for Oligocene sea level falls in the mid-Pacific region is derived from the stratigraphic rec- ord revealed by deep drilling operations on Enewetak Atoll (Ladd et al., 1953; Cole, 1957; Schlanger, 1963). Guyots and atolls are excellent recorders of sea level falls and subsidence of the surrounding seafloor. Although in most cases the carbonate-producing capacity of reef ecosystems allows the atoll to maintain itself at sea level despite basement subsidence and sea level rises, sea level lowerings cause the atoll to emerge as a high limestone island. The limestone above sea level and within the Ghyber-Herzberg freshwater lens that develops within the emergent atoll is subjected to massive diagenesis involving solution of much original aragonite skeletal material and the deposition of calcite cement and dolomitization. Karstic surfaces develop atop the emerged island. Upon resubmergence the new capping unaltered sediment may remain atop the diagenetically altered older atoll. The contact between the altered and unaltered limestones is a solution unconformity (Schlanger, 1963).

The stratigraphic record at Enewetak Atoll is characterized by several solution unconformities of Oligocene, middle Miocene and Pliocene-Pleistocene age. Dating of these atoll limestones is determined by large benthic foraminiferal assemblages using the Far East Letter Code and correlated with planktonic foraminiferal zones (Cole, 1957; Haak and Postuma, 1975). The basalt edifice below the present atoll formed in Paleocene-early Eocene time (Kulp, 1963). Subsidence took place throughout Eocene time with the deposition of at least $420 \mathrm{~m}$ of reef and shallow-bank limestone atop the volcanic edifice; the limestones directly below the solution unconformity, now $850 \mathrm{~m}$ below sea level, contain late Eocene (Tb zone) large benthic foraminifers (Cole, 1957). The section is completely lacking in foraminifers characteristic of the early Oligocene (Tc and Td) state, and the entire Tb section is characterized by petrographic features indicative of subaerial exposure or diagenesis in the freshwater Ghyben-Herzberg lens. The missing Tc-Td section and the presence of late $\mathrm{Tb}$ fossils indicate that the atoll was emergent in Oligocene time and that some TcTd sediments were deposited and later removed during the lowering of the atoll surface by solution. Deposition of reefal carbonate at Enewetak resumed in late Oligocene $\left(\mathrm{Te}_{1-4}\right)$ time, but the exact time of resumption within that interval is unknown. The P21 and P22 turbidite events at DSDP Sites 462 and 315 took place in $\mathrm{Te}_{1-4}$ time. Thus at Enewetak the span of the hiatus represented by the missing Tc-d section and the turbidite events would be correlative with the major offlap events on the New Jersey and Irish passive margins.

The magnitude of the Oligocene sea level fall relative to present sea level in P21 Zone time can be determined by combining data on the subsidence path of Enewetak Atoll (Cole, 1957; Kulp, 1963; Crough, 1978) and the present depth to the solution unconformity at $850 \mathrm{~m}$ below sea level in light of late Paleocene and early Eocene sea level estimates (Vail and Hardenbohl, 1979). At the time of the formation of the volcanic edifice, sea level was, using Vail and Hardenbohl's (1979) estimate, 150 to $200 \mathrm{~m}$ above present sea level. The top of the volcanic peak must have been at or above sea level in order that the late Eocene reef limestone could form. The subsi- 
dence path of Enewetak Atoll can be determined from the drilling data on present depths to dated horizons and a predicted path based on the argument of Crough (1978) that Enewetak is subsiding as if it was now on Mesozoic oceanic crust that had been uplifted by thermal rejuvenations to an elevation characteristic of seafloor 25 m.y. old. Thus the top of the volcanic edifice has subsided from $\sim 200 \mathrm{~m}$ above present sea level to $1270 \mathrm{~m}$ below present sea level. During P21 Zone time at $30 \mathrm{Ma}$ the volcanic basement was therefore $450 \mathrm{~m}$ below present sea level and at least $410 \mathrm{~m}$ of Eocene limestone and some unpreserved thickness of Oligocene limestone had accumulated prior to the formation of the solution unconformity. In order for the solution unconformity to have developed at $30 \mathrm{Ma}$ sea level must have been at least $100 \mathrm{~m}$ below the present sea level.

In summary, the presence of turbidites, composed of reef and shallow-bank skeletal debris, and the Oligocene hiatus below Enewetak Atoll point to major emergence events on mid-Pacific atolls during P21- and P22-Zone times at the same time that hiatuses were forming on passive margins. The analysis of Schlanger and Premoli Silva (in press) argues for the truly global extent and synchroneity of the previously postulated Oligocene sea level falls. Further, their estimate of mid-Oligocene sea level relative to present sea level is in accord with the estimate of Vail and Hardenbohl (1979), who proposed a mid-Oligocene sea level at $\sim 150 \mathrm{~m}$ below present based on seismic stratigraphic studies of passive margins. These estimates are, however, significantly greater than the $35-\mathrm{m}$ relative sea level fall during mid-Oligocene time proposed by Miller et al. (1985), which is based on correlation of high $\delta^{18} \mathrm{O}$ values with ice volume changes.

\section{Oceanic Crust}

The main purpose for drilling at Site 565 was to recover deposits of the Jurassic-age megaocean and its basement. Extrapolation $1000 \mathrm{~km}$ northwest from mapped magnetic anomaly M-25 of the Phoenix lineations (Candé et al., 1978) suggested a basement age for the site of about 150 to $170 \mathrm{Ma}$ (Callovian to Bajocian).

The site survey (Shipley et al., 1983) showed a prominent reflection at $9.0 \mathrm{~s}$, which was predicted to be the top of Jurassic limestones found above the CCD on the flanks of the ridge crest. Some irregular deeper reflectors at $9.1 \mathrm{~s}$ were thought to be the basement. Depths to the 9.0- and 9.1-s reflectors were estimated to be at about 850 and $1000 \mathrm{~m}$.

Drilling at Site 585 encountered a thick mid-Cretaceous section of volcaniclastic sedimentary rocks. Drilled thickness and seismic-velocity properties of cores allowed correlation of the 9.0-s reflector with the marked decrease in drilling rate at $800 \mathrm{~m}$ in Hole $585 \mathrm{~A}$, within the mid-Cretaceous section. Subsequent interpretation of digitally recorded seismic profiles obtained on Leg 89 allowed correlation of the 8.96 -s reflector, and a $45 \%$ velocity increase, with the 800-m level (Whitman, this volume). Glomar Challenger records show reflections deeper than observed during the site survey and deeper than we drilled. Acoustic basement is at least $9.2 \mathrm{~s}$ deep at Site 585 , and appears to be at $9.5 \mathrm{~s}$ where profiled a few $\mathrm{km}$ north of the site. Assuming no significant change in the velocity-depth function, and that the records do show basement rather than a layer over it, Whitman et al., (this volume) predict basement to be $1200 \mathrm{~m} \mathrm{(9.2} \mathrm{s)} \mathrm{be-}$ low the seafloor, or $300 \mathrm{~m}$ below the total depth of Hole 585A. It may, however, be at $1700 \mathrm{~m}(9.5 \mathrm{~s})$. They suggest that Jurassic carbonates may be present below the volcanogenic section and above basement.

Thus drilling at Site 585 provided no information about the nature of the crust. Its specific age also remains unknown, but its Jurassic age prediction has been strengthened by its record of subsidence. An alternative to the Candé et al. (1978) Jurassic interpretation was given by Kroenke (in Hilde et al., 1977) as Cretaceous. The subsidence curve, however, shows that a $1700-\mathrm{m}(9.5 \mathrm{~s})$ basement for the East Mariana Basin, isostatically corrected for sediment loading, would be too deep for Cretaceousage lithosphere. Indeed, Whitman et al., (this volume) interpret the subsidence as being too deep for the Parsons and Sclater (1977) age versus depth relationship because it fits almost exactly a simple $t^{1 / 2}$ curve rather than the Parsons and Sclater (1977) empirical relationship that combines $\mathrm{t}^{1 / 2}$ younger than $70 \mathrm{Ma}$ with a flatter curve older than $70 \mathrm{Ma}$. To account for the depth, Whitman et al., (this volume) suggest that a "cold spot" in the mantle may underlie the East Mariana Basin. Rather than that explanation, we prefer an explanation that the Sclater curve should be $\mathrm{t}^{1 / 2}$ both before and after $70 \mathrm{Ma}$, with the East Mariana Basin as a valid point on it. We believe that depth points selected by Parsons and Sclater in the Central and Western Pacific basins are in locations of Cretaceous midplate volcanism, and therefore had their thermal histories interrupted. Midplate volcanism in the East Mariana Basin was not at Site 585 but rather was at the seamounts around it.

\section{Cretaceous Volcanism in the East Mariana Basin}

\section{Lowest Record}

Volcanic and carbonate sediments, emplaced by gravity-flow processes, are evidence of the mid-Cretaceous growth of volcanic seamounts and islands around the East Mariana Basin, and also record the history of the carbonate caps and later subsidence of the volcanic edifices. Although anticipated by members of the scientific party of the leg, extensive volcanic sedimentary rocks were not predicted in the site survey report (Shipley et al., 1983).

The volcanogenic sandstones, siltstones, claystones, and breccias from 590 to $893 \mathrm{~m}$ (total depth) at Site 585 (shown on Fig. 7) have been assigned to Unit VI (Site 585 report, this volume). Most of the grains are hyaloclastite, volcanic glass broken by internal stresses from sudden quenching as lavas erupted in contact with water. The granulated mafic glass, now pervasively altered, was transported from its original location to the basin floor and deposited there. Tracing along seismic reflection profiles confirms the evidence from included shallow-water carbonate debris that seamounts around the rim of the eastern East Mariana Basin were sources for Unit VI. Its age is late Aptian to early Albian. 
The lower part of Unit VI is mainly a breccia characterized by abundant angular to subrounded tabular clasts of hyaloclastic sandstone and siltstone, as well as basalt. The basalt clasts are pebbles, some cobbles, and a few boulders, supported by a matrix of sand- and silt-sized hyaloclastite glass. That fabric, along with a general lack of bedding, indicates that the rocks below about $850 \mathrm{~m}$ were deposited from debris flows. Petrographic and geochemical analysis of several of the larger pebbles shows them to be plagioclase-olivine and plagioclase phyric hypocrystalline basalts as well as hyaloclastites composed of cemented glass fragments. All are quartz-normative tholeiites that had undergone slight submarine weathering before they slumped and were incorporated into debris flows (Floyd, this volume). The grains are weakly to nonvesicular tachylite and altered sideromelane, with vesicle sizes suggesting they had erupted at submarine depths of perhaps 300 to $400 \mathrm{~m}$. The pebbles and sand formed nonexplosively as particles fairly high on volcanic slopes that became unstable and slumped. The slumped masses broke into debris flows that were deposited on the plain of the East Mariana Basin.

The bottom two cores of Hole 585A lack carbonate debris, but the upper part of the debris-flow sections has ooids, oncoids, and fragments of rudist pelecypods. By that time in the late Aptian one or more of the volcanoes had reached shallow water. Their tholeiitic composition was slightly more enriched than MORB (Viereck et al., and Floyd, this volume).

\section{Main Turbidite Record}

The section between 590 and about $850 \mathrm{~m}$, which is the main part of Unit VI, is a sequence of graded turbidites of dominantly sand-sized hyaloclastite. There is, however, a textural range from fine pebbles at the base of some turbidites to silt throughout the beds, and components other than hyaloclastite characterize certain beds.

Nearly 400 turbidites were identified and their thicknesses measured (Whitman et al., this volume). More than two dozen are thicker than $1 \mathrm{~m}$ and a few are nearly $4 \mathrm{~m}$ thick, but most are thinner than $0.5 \mathrm{~m}$. The thickest turbidites are in the middle and lower part of the section. The turbidites have a variety of sedimentary structures, including scoured and load-cast bases, grading, ripple cross-bedding, and bioturbation of pelagic layers, which show the Bouma divisions. Many contain the complete A through E sequence (Fig. 11). Characteristically, the base of division A may contain fine pebbles and sand of shallow-water carbonate debris (Haggerty and Premoli Silva; and Whitman et al., this volume) and of vitric, lithic, and crystal volcanic debris (Floyd; Floyd and Rowbotham; and Viereck et al., this volume).

Pyroxene compositions show two volcanic sources, tholeiitic basalt as well as alkali basalt (Floyd and Rowbotham, this volume). Some hawaiitic and mugearitic basalt clays are tentatively identified (Viereck et al., this volume). According to the geochemistry, mineralogy, and petrology of the volcanic debris, the seamounts and island sources for the mid-Cretaceous turbidites at Site 585 resembled island chains like Hawaii (Fig. 12).

The turbidite sand has angular, equant, blocky to cuspate shapes, altered sideromelane composition, and ves-

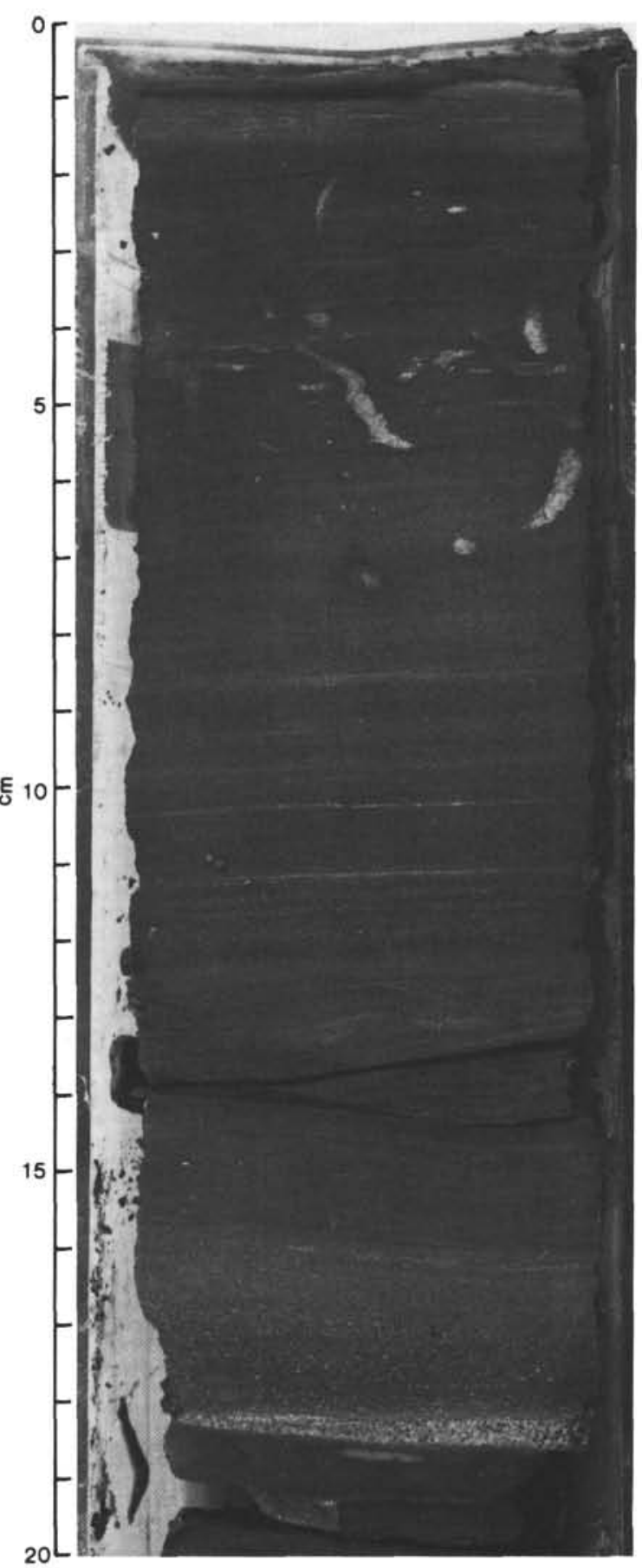

Figure 11. Carbonate and volcaniclastic turbidite, from the core catcher of Core 89-585-39, showing complete Bouma sequence.

icle size and abundance that indicates its hydroclastic origin. Most apparently formed by nonexplosive spalling below the volatile compensation depth (Fisher and Schmincke, 1984). Throughout the section, and especially in one 11-m interval (Core 47 and the upper part of Core 48 , near $680 \mathrm{~m}$ ) the abundant highly vesicular basalt glass suggests and relatively shallow-water submarine eruption.

The provenance of the turbidites was mainly the upper submarine slopes and shallow submarine caps of one or more of the volcanic seamounts and islands around 


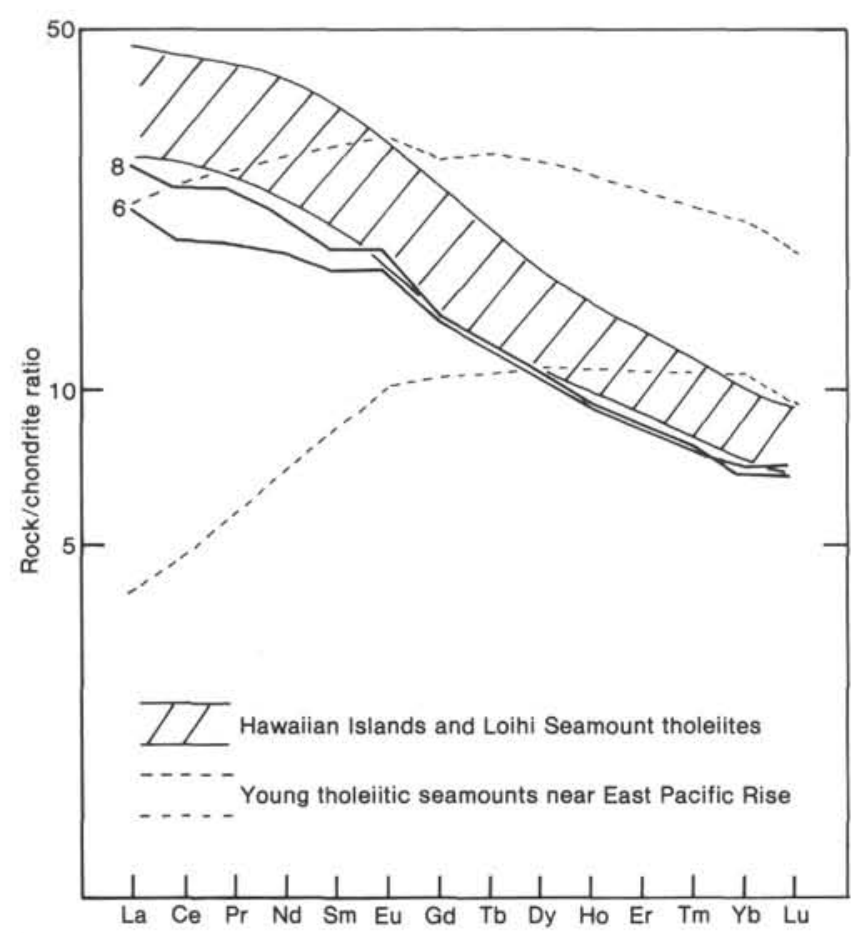

Figure 12. Chondrite-normalized REE pattern of Mariana Basin Aptian volcanoes compared to patterns for midplate volcanoes and ridge-crest volcanoes. Samples 6 and 8 are, respectively, the most primitive members of Floyd's (this volume) groups B (plagioclase and olivine-phyric tholeiitic basalt) and $\mathrm{C}$ (plagioclase-phyric tholeiitic basalt).

the basin. Some of the ooids have nuclei of sand-sized basalt, altered glass, or clinopyroxene. In addition, Viereck et al., (this volume) interpret some vesicular clasts and all crystalline basaltic clasts to have formed and eroded above sea level. Holocrystalline basalt grains may make as much as $25 \%$ of samples in a debris flow (Core 54 , near $740 \mathrm{~m}$ ) within the mainly turbidite section. It should be noted that this same level also yielded the clast of fine-grained epidote amphibolite (Floyd, this volume) that perhaps came from metamorphosed ocean crust or deep within a volcanic edifice, and was subsequently ejected or eroded from a fault scarp.

The upper one-third of the turbidite section of Unit VI generally has thinner turbidites than below. Lithic grains decrease upward in size and abundance. Crystal fragments are small, but include rare apatite and titanaugite, also suggesting that some of the volcanism was alkaline (Floyd, this volume).

\section{Alteration of Mid-Cretaceous Volcanogenic Sediments}

The volcaniclastic section of Site 585 is pervasively altered to palagonite, phyllosilicates, zeolites, analcime, and other secondary minerals. Preserved sideromelane is rare, whereas fresh phenocrysts and microlites of pyroxene and plagioclase are moderately common. Clinoptilolite and phillipsite in the mineral assemblages are characteristic of the lower end of the zeolite facies, representing alteration temperatures certainly less than $60^{\circ} \mathrm{C}$. Chapters in this volume describing the alteration are by
Floyd, Floyd and Rowbotham, Chamley et al., and Viereck et al.

Palagonite is ubiquitous. The phyllosilicates are smectites, interlayered smectite-chlorites, and celadonite. Clinoptilolite and sodium-rich chabazite or phillipsite are more common zeolites than are natrolite and heulandite. Analcime is especially common. Calcite and small amounts of barite, hematite, palygorskite, a calcium sulfate, apophyllite, leucoxene, albite, and opal are other secondary components. Textural sites of secondary minerals are the glassy grains and coarser clasts, the matrix of these clasts, phenocrysts in clasts, vesicles, pores and vugs, and late veins.

Palagonitized glass is most commonly yellow to brown and isotropic to weakly birefringent, typically has shrinkage cracks, and may be banded in shades of green or brown. Its composition is mainly cryptocrystalline smectite with large amounts of absorbed water. Spherical leucoxene aggregates characterize the darker bands. Other areas may be enriched in $\mathrm{Fe}$ or $\mathrm{Mg}$. Granular to fibrous or platy microcrystalline green or yellow smectite replaces palagonite, beginning at grain and vesicle surfaces. Or, in many instances, zeolite replaces the palagonite. The paragenesis may differ from sample to sample and can be complex (Viereck et al.; and Floyd, this volume).

Smectites are the phyllosilicate minerals of greatest abundance in the Cretaceous volcaniclastic section. In the lowest part cored a highly crystallized and sodiumrich magnesium smectite, probably a saponite, is associated with celadonite, amorphous aluminum oxides, and lesser chlorite and mixed-layer clays. The smectite replaces glass fragments and matrix, and fills parts of zoned vesicles. Smectite or chlorite or both replaces olivine phenocrysts and microlites and fills vesicles of these Aptian turbidites and debris flows.

Above Core $48(686 \mathrm{~m})$ are reworked and graded hyaloclastites and the highest of the coarser turbidite beds. Their smectites are less well crystallized, having fleecy to lathed morphology. Chlorite is more abundant but shows poorer crystallinity, and traces of illite are present as a micaceous phyllosilicate, but celadonite has disappeared. $\mathrm{Mg}$-beidellite and $\mathrm{Mg}$-chlorite occur in Core 46.

From the uppermost Albian to upper Campanian $(590-476 \mathrm{~m})$ the beds are fine grained but still contain a large volcanogenic component. Smectites are poorly crystallized, typically having a fleecy morphology. The claylike mineral palygorskite occurs in Cores 34 and 35. Clay mineralogy, chemistry, and morphology of the Cretaceous sediments are described in detail by Chamley et al. (this volume). Floyd (this volume) and Viereck et al. (this volume) describe the petrographic relationships of replacement and vesicle filling as well as provide additional mineralogical and geochemical information.

Clinoptilolite is the zeolite of the claystones in the Cretaceous section above $590 \mathrm{~m}$. Its habit is chiefly as granular to radiate-fibrous zeolite spheroids. A controversy exists about the zeolite in the coarse-grained section below that depth. Floyd (this volume) and Viereck et al. (this volume) each give several chemical analyses that overlap one another and that overlap the composi- 
tional ranges both of phillipsite and of chabazite. Phillipsite, however, differs structurally from chabazite, and both Floyd and Viereck et al. used X-ray diffraction methods of identification. Floyd reports abundant phillipsite containing a wide range of alkali content; Viereck et al. report abundant sodium-rich chabazite, recognizing phillipsite only as relict structures now replaced with later analcime.

In the deepest sections, natrolite fibers and plates are present, replacing crystals or filling vesicles. Natrolite and heulandite also may fill veins cutting the sandstones and breccias. Analcime, considered to be a zeolite by some mineralogists, is common in the reworked hyaloclastites and other turbidites and debris flows in the midCretaceous section. Clean analcime replaces glass (or palagonitic glass) and, less commonly, plagioclase. Inclusion-rich analcime has filled pores, where apparently it has replaced earlier prismatic phillipsite cement, and may also have replaced margins of glassy grains.

The occurrences of small amounts of such minerals as calcite, barite, leucoxene, albite, and opal in the volcaniclastic sediments are noted in several chapters in this volume (Chamley et al., Viereck et al., and Floyd et al.).

These same writers also describe the alteration history of the volcaniclastic sediments at Site 585. Alteration took place in two stages. The earlier alteration occurred on the flanks and near the tops of the seamounts that were the sources of the sediments. Some evidence cited by Floyd (this volume) includes ooids nucleated on smectite-replaced vesicular glass, and sideromelane enclosing a palagonitized fragment with smectite-infilled vesicles. This early stage is represented by development of palagonite, smectite, minor hematite, and possibly of celadonite. Subsequently, the partly altered to fresh hyaloclastite slumped from the flanks of the seamounts and was transported in debris flows and turbidity currents to the location of Site 585 .

Floyd (this volume) sees no evidence that there was an epiclastic or pyroclastic component of the earliest volcanogenic sediment, and Viereck et al. (this volume) conclude that the earliest sediment in sideromelane and tachylite hyaloclastite formed mainly by quenching and spalling of submarine pillow lavas and sheet-flow lavas. Chamley et al. (this volume) believe, however, that the abundance of fixed or absorbed sodium in most of the secondary minerals is a marker of subaerial volcanism. The textural evidence seems far more important than the chemical evidence.

Burial of the volcanogenic sediment was rapid, as the secondary minerals gained much less $\mathrm{K}$ (in phillipsite and celadonite), $\mathrm{Rb}$, and $\mathrm{Ba}$ than expected in comparison to many other sites where the effects of seafloor alteration have been studied (Viereck et al., this volume). The modest increase in $\mathrm{K}$ above Core 585A-16 may relate to celadonite abundance, with the celadonite having replaced trachytic rocks, after a change from the initially tholeiitic volcanism, according to Chamley et al. (this volume).

Clinoptilolite and phillipsite, along with the abundant smectite and celadonite, characterize the lower end of the zeolite facies, and represent alteration temperatures at the seafloor or under modest depths of burial. Cela- donite and saponite smectite are the two characteristic clays that form in the near-surface alteration of oceanfloor basalts (Cann, 1981). The analcime below about $670 \mathrm{~m}$, well-crystallized smectite below about $686 \mathrm{~m}$, and the zeolite veining (including heulandite) and zeoliterimmed vugs below about $820 \mathrm{~m}$, along with the downhole decrease in clinoptilolite, are suggestions of increased diagenesis in the deepest sediments, but well within the zeolite facies.

Overall in the Cretaceous, Chamley et al. (this volume) characterize the late Aptian to Maestrichtian nonbiogenic sedimentary history as being first dominated by closely adjacent volcanogenic sources, then by more distal volcanic sources, and finally by the development of distant detrital sources.

\section{THE NAURU BASIN IGNEOUS COMPLEX}

\section{Sheet-Flow Basalts Recovered on Leg 89}

During the Leg 89 reoccupation of Site 462 , we reentered and cored Hole $462 \mathrm{~A}$ an additional $140.5 \mathrm{~m}$ to a total sub-bottom depth of $1204 \mathrm{~m}$. The newly recovered basalts of Cores 93 through 109 were described and analyzed, and the new results were compared with the earlier Leg 61 observations and conclusions.

An additional 12 volcanic units, numbered 45 through 56 and shown in Figure 13 were recognized below the volcanic units cored and described during Leg 61 (Batiza et al., 1981). These deeper units are interlayered aphyric and sparsely clinopyroxene-plagioclase-olivine phyric, nonvesicular basalts. The textures and other characteristic features indicate that the 12 units are all sheet flows. Thin, reworked hyaloclastite layers overlie units 45,46 , and 47 , and resemble the thin sedimentary intercalations described within the higher basalt layers (Moberly and Jenkyns, 1981). The lavas are olivine-normative and quartz-normative tholeiite basalts with low abundances of the incompatible trace elements. They are a deeper continuation of the type 2 or type B basalts (Larson, Schlanger, et al., 1981) of Cores 80 to 92 . Although in general little systematic mineralogical or chemical changes occur between samples, there is enough to allow three groupings based on content of siderophile elements and in compatible trace elements, and on slight differences in $\mathrm{TiO}_{2}$ content (Floyd, this volume). The threeway division of the whole complex by Batiza et al. (1980) was also based on $\mathrm{TiO}_{2}$ content, as well as on other criteria, but those $\mathrm{TiO}_{2}$ differences are larger than those of the three so-called megagroups (Fig. 14) of Floyd within the type 2 basalts. According to Floyd (this volume), the chemical variation displayed can be related to fractionation of the phenocryst phases. Floyd's megagroup A, in units 45 to 47 , apparently resulted from fractionation of clinopyroxene, and probably also of olivine, but alteration obscures the trends. Megagroup B is in units 48 through 52 (upper part), and probably resulted mainly from fractionation of olivine and plagioclase with relatively little contribution from fractionation of clinopyroxene. Plagioclase fractionation is the important factor leading to megagroup $C$, found in the lower part of unit 52 into unit 56, the deepest unit cored. Further division 


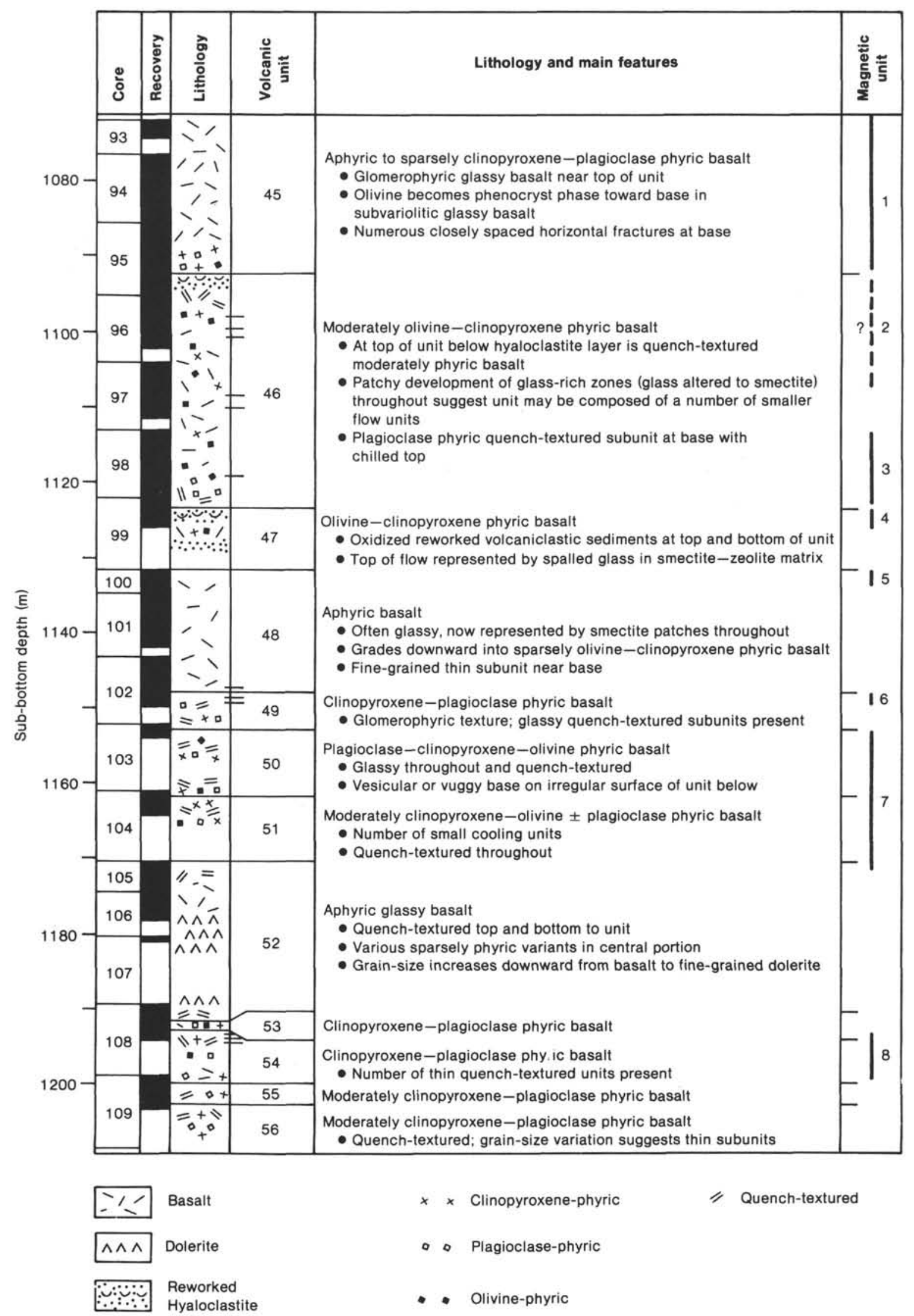

Figure 13. Section of sheet-flow basalts drilled in Hole 462A during Leg 89, showing lithology of the 12 volcanic units recovered. 
SEDIMENTARY AND VOLCANIC HISTORY

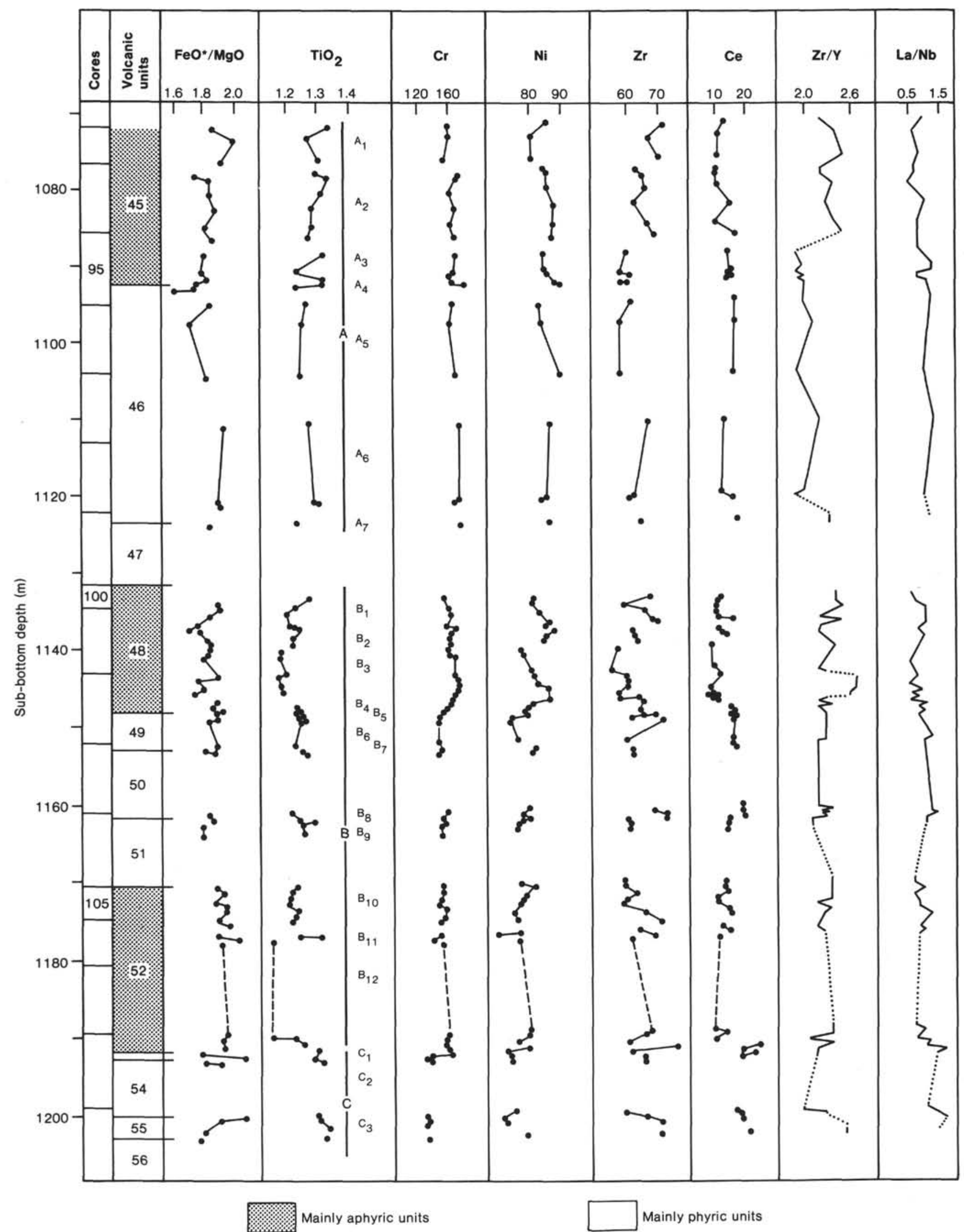

Figure 14. Chemical stratigraphy of basalts drilled in Hole 462A during Leg 89, showing the distribution of Floyd's (this volume) groups A, B, and $\mathrm{C}$, and their subgroups. 
into 22 small geochemical subgroups may have resulted from eruption of separate magma pulses undergoing further minor fractionation or flow differentiation. Complexities in the rapid cooling of the flows is reflected in their anisotropic physical properties (Fujii and Hamano, this volume).

Clinopyroxene glomerocrysts are mainly Ti-poor augites, whereas the quenched clinopyroxenes are relatively richer in $\mathrm{Ti}$ and show considerable varieties in $\mathrm{Ca}$ abundance. Plagioclases are mainly labradorites, although some zoned plagioclase glomerocrysts range from $\mathrm{An}_{73}$ (bytownite) to $\mathrm{An}_{20}$ (oligoclase). The more calcic plagioclases generally have higher $\mathrm{Mg}$ and $\mathrm{Fe}$ contents. These basalts underwent low-temperature submarine anoxic alteration to golden brown palagonite and brownish smectite that replaced interstitial glass and celadonite that replaced plagioclase (Floyd and Rowbotham, this volume). Alteration, as indicated by $\mathrm{H}_{2} \mathrm{O}$ and $\mathrm{Fe}_{2} \mathrm{O}_{3} / \mathrm{FeO}$ analyses (Fig. 15), is relatively slight, suggesting that these basalts erupted too rapidly for extensive submarine weathering.

Nauru Basin basalts have ratios of $\mathrm{La} / \mathrm{Sm}, \mathrm{La} / \mathrm{Yb}$, $\mathrm{Nb} / \mathrm{Zv}, \mathrm{La} / \mathrm{Ta}$, and $\mathrm{Th} / \mathrm{Hf}$ that are chondritic. $\mathrm{La} / \mathrm{Ta}$ for these and other basalts is shown on Figure 16. The ratios of $\mathrm{La} / \mathrm{Yb}, \mathrm{Nb} / \mathrm{Zr}$, and $\mathrm{Ta} / \mathrm{Zr}$ are higher than $\mathrm{N}$-type MORB, more closely resembling T-type MORB from the Reykjanes Ridge, transitional between ridgecrest and ocean-island basalts for these trace elements (Saunders, this volume). Castillo et al. (this volume) show that whereas Nauru Basin ${ }^{143} \mathrm{Nd} /{ }^{144} \mathrm{Nd}$ ratios resemble

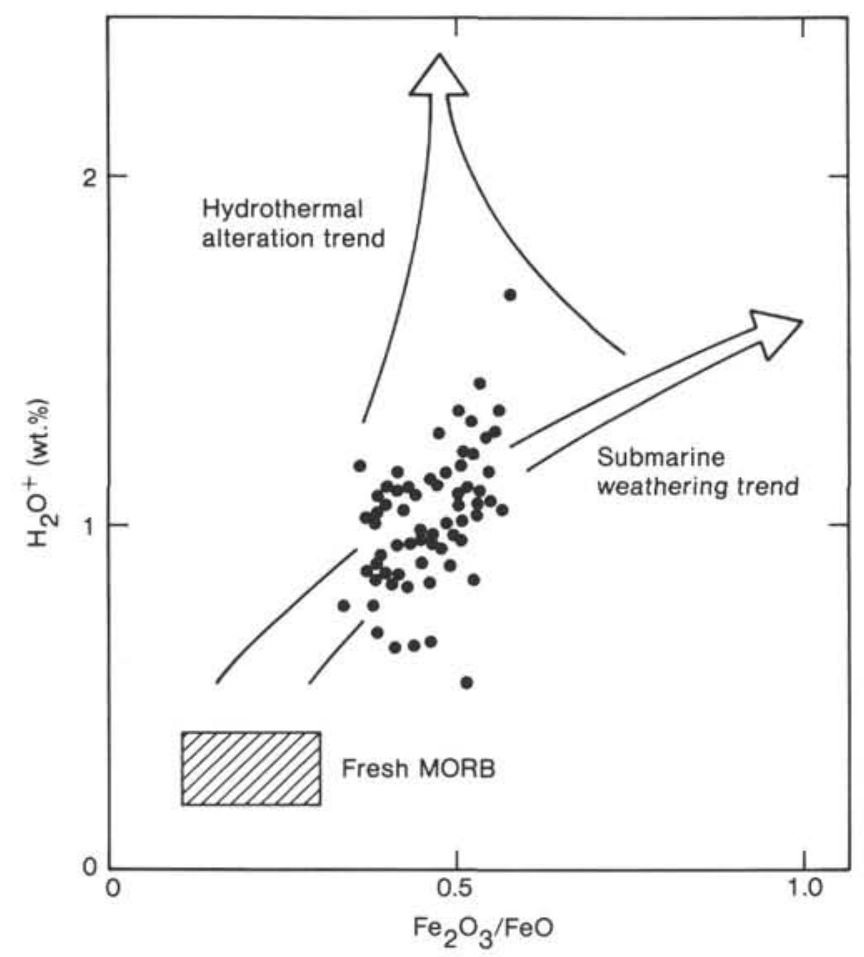

Figure 15. Hydration $\left(\mathrm{H}_{2} \mathrm{O}^{+}\right)$and oxidation $\left(\mathrm{Fe}_{2} \mathrm{O}_{3} / \mathrm{FeO}\right)$ of Hole $462 \mathrm{~A}$ basalts relative to typical trends of alteration of basalt (See Floyd, this volume.) those of $\mathrm{N}$-type MORB, their ${ }^{87} \mathrm{Sr} /{ }^{86} \mathrm{Sr}$ ratios resemble those of ocean-island basalts.

\section{Origin of the Igneous Complex}

\section{Magma Generation and Evolution}

Although the rocks of the Nauru Basin sill and flow complex generally resemble one another in gross chemical and mineralogical aspects, different levels or degrees of difference do exist and can be used to indicate the origin and evolution of their magmas.

At the highest level the basalt types differ in their gross $\mathrm{TiO}_{2}$ and La contents (Fig. 17) and also in their stratigraphic grouping and paleomagnetic inclinations (Castillo et al., this volume). Type 1 basalt has the lowest $\mathrm{TiO}_{2}$ values, and occupies the highest $250 \mathrm{~m}$ of the sheet-flow section (Figs. 17 and 18). Below it is type 2 basalt, with intermediate $\mathrm{TiO}_{2}$ values; the new samples from Leg 89 coring of deeper sheet flows are all of this type. Also, type 2 basalt occurs in the lower sills (Cores 36-41) of the interbedded sills and sediments that comprise the upper part of the complex. Type 1 basalt, of highest $\mathrm{TiO}_{2}$ values, is found in the highest sills. Saunders (this volume) also recognizes the division of the sheet flows (his II equals type 1 of Castillo et al., and III equals lower 2), but Saunders put all sill rocks into one group (his I), perhaps because he doubts that they are sills and had only a few analyses.

Isotopic evidence bears heavily on the problem of the origin of these magmas. According to Castillo et al. (this volume), all basalts of the igneous complex came from a common source, because the ${ }^{87} \mathrm{Sr} /{ }^{86} \mathrm{Sr}$ ratios vary only slightly. Differences among the three types are ascribed to different degrees of partial melting in the source region of the mantle (Castillo et al.; and Notsu et al., this volume); examination of simple models suggests that the onset of volcanism resulted from a batch of magma that underwent a modest amount of partial melting (type 2), followed by the peak of volcanism with more extensive partial melting (type 1). Considerably later (see age discussion below), the sills came from magma batches that formed from modest (type 2) and slight (type 3 ) amounts of melting.

As several of the contributors to this volume stated (and as Floyd shows in detail), the next level of magma differentiation has resulted from fractional crystallization of the phenocryst phases. The type 2 flows have at least three such groups. The finest scale or level of differentiation seems to have occurred as separate magma pulses underwent additional fractionation or flow differentiation.

\section{Tectonic Setting}

A major question arose from the Leg 61 discoveries. How can a laterally extensive, tabular mass of MORBlike basalt (Fig. 19) more than $600 \mathrm{~m}$ in thickness have been emplaced without disturbing the underlying crust enough to destroy the $\mathrm{M}$-series magnetic anomalies in the wide, flat-floored Nauru Basin? This problem was addressed by Larson and Schlanger (1981). Structurally, 


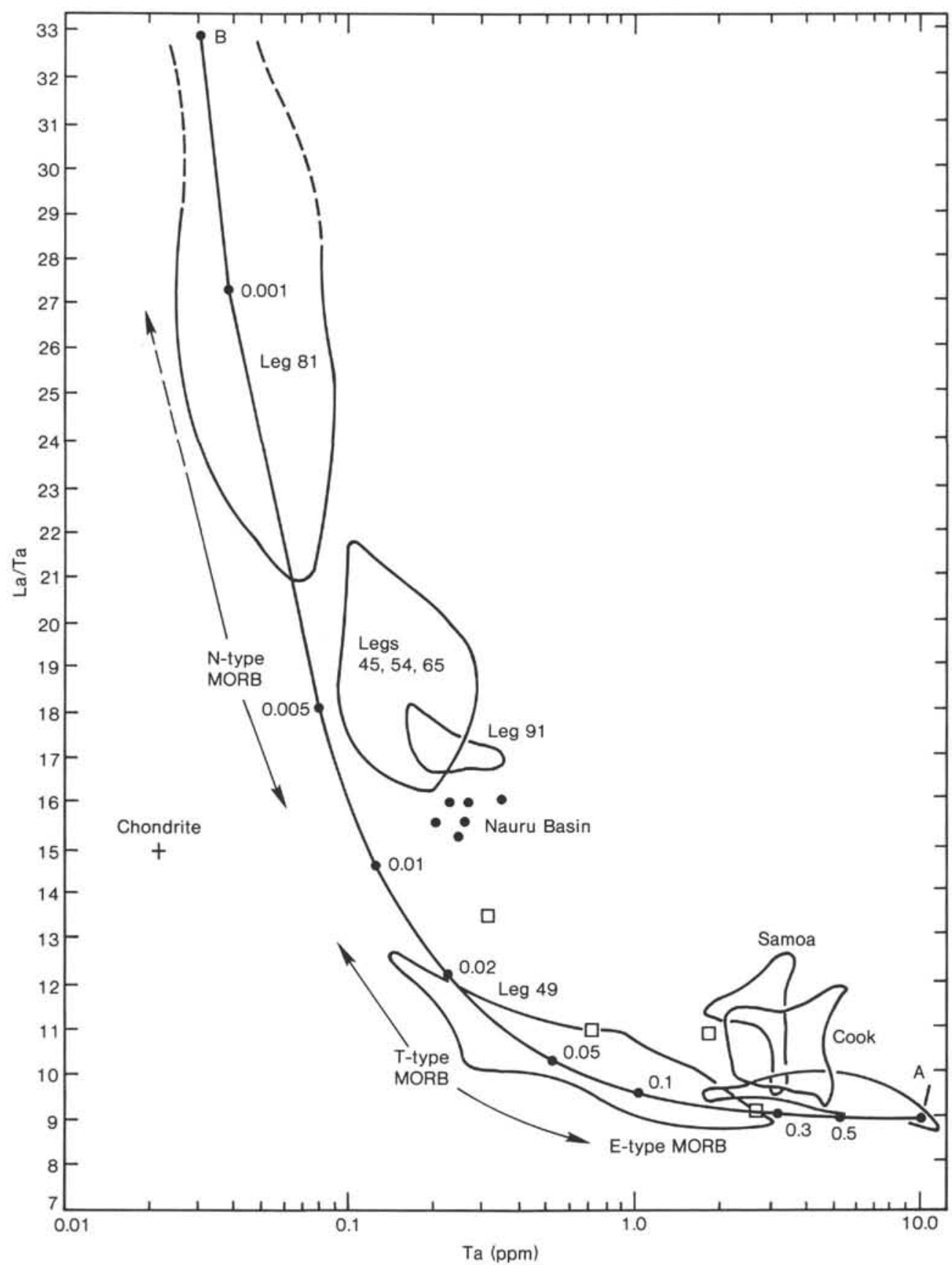

Figure 16. Plot of $\mathrm{La} / \mathrm{Ta}$ versus Ta, showing Nauru Basin analyses relative to other oceanic basalts. (See discussion in Saunders, this volume.)

the MORB-like basalt must have erupted much like continental floor basalts (Saunders, this volume), that is to say, rapidly and from fissures and not from edifice-building central vents. Regionally, there is no evidence whatsoever of a hot-spot plume trace. Perhaps there were numerous short-lived propagating rifts, giving numerous tiny, ephemeral microplates (Castillo et al., this volume), as had been suggested for a Cretaceous western Pacific ridgecrest setting by Kroenke (in Hilde et al., 1977), except the preserved M-series anomalies show there was no significant spreading.

It is interesting that various tectonic discrimination diagrams give little help in indicating the tectonic setting of the Nauru Basin igneous complex, whose basalts fit best with island-arc tholeiites (Fig. 20) or mid-ocean ridge tholeiites (Figs. 16 and 19).

\section{Episodes of Igneous Activity in the Nauru Basin}

Site 462 is on Anomaly M-26. There has been no new information to alter our opinion that the lithosphere at Site 462 formed at M-26-time, about 145 Ma.

The sheet-flow basalt lavas provided radiometric ages of 131 Ma (Ozima et al., 1981, age spectrum ragged) from Core 462A-50, $127 \mathrm{Ma}$ (S. Hart quoted by Castillo et al., this volume) from an undesignated part of the sheet flows, and $129 \mathrm{Ma}$ (Takigami et al., this volume) 

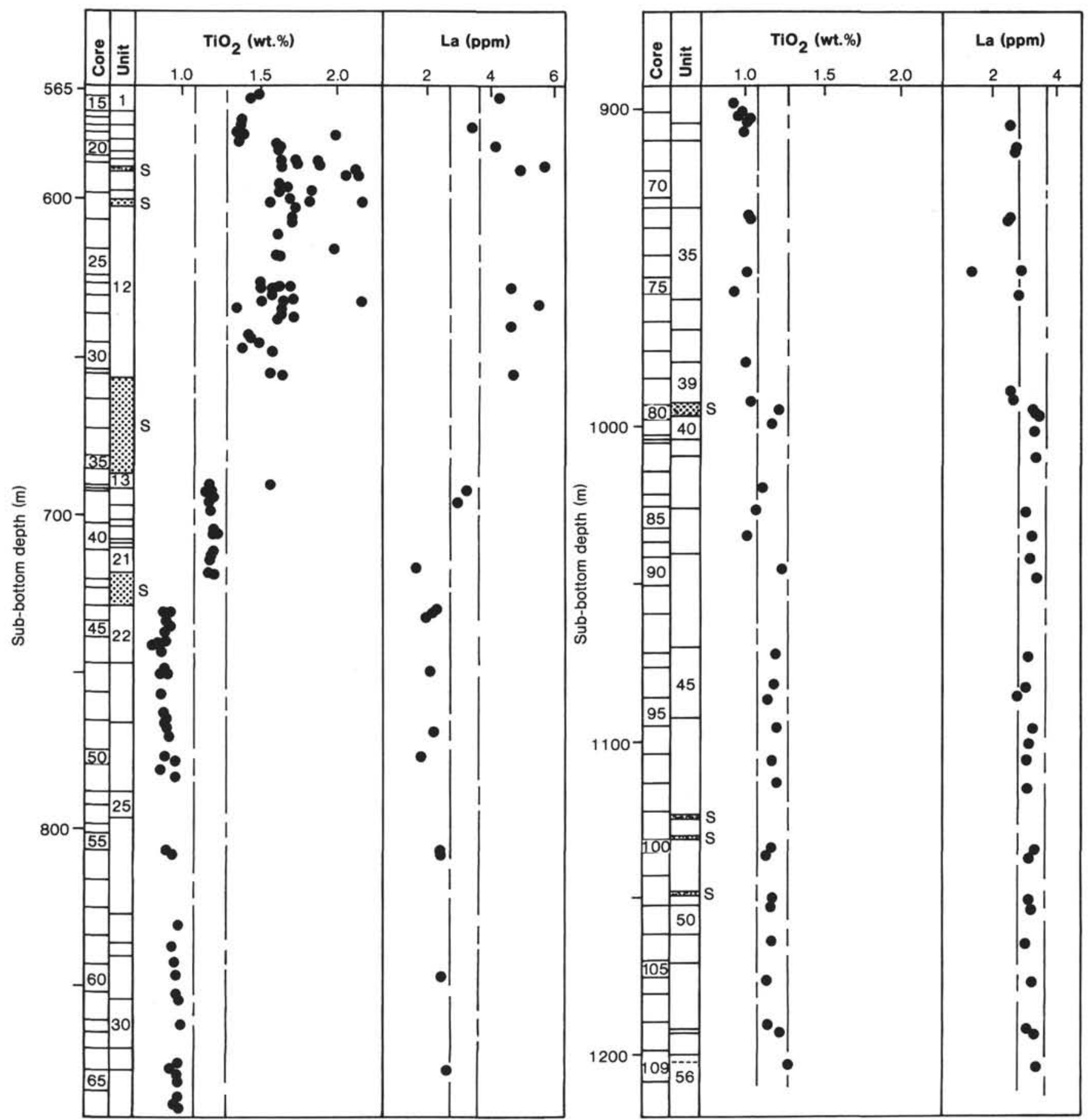

Figure 17. Variation in $\mathrm{TiO}_{2}$ and $\mathrm{La}$ in the Nauru Basin igneous complex. Dashed vertical lines separate three basalt types: (1) low $\mathrm{TiO}_{2}$ and $\mathrm{La}$ values in flows between Cores 43 and 79; (2) intermediate values in sills between Cores 36 and 43 and in flows between Cores 80 and 109 , and (3) high values in sills between Cores 14 and 32. (See discussion in Castillo et al., this volume.)

from Core 462A-108 (T.D.). Thus the likely radiometric age of these rapidly erupted flows is about 127 to 131 $\mathrm{Ma}$, or Valanginian. The sample with rare, poorly preserved radiolarians in Core 99 yielded only one species that could be positively identified; it ranges from latest Jurassic to earliest Aptian (Schaaf, this volume) and so is compatible with an age in the 127 to $131 \mathrm{Ma}$ range. As pointed out by Schaaf, the presence of a late Tithonian-early Berriasian fauna in Core $462 \mathrm{~A}-46$ indicates reworking from an older sediment source exposed in the Basin.

Above the flows is a sedimentary section extending from the Aptian to the Recent, with sills intruded into sediments as high as upper Albian or Cenomanian (i.e., the highest sills should be no older than late Albian, about $100 \mathrm{Ma}$ ). The Aptian and Albian hyaloclastic sediments intruded by the sill complex are by themselves evidence that the Aptian-Albian Pacific igneous episode 


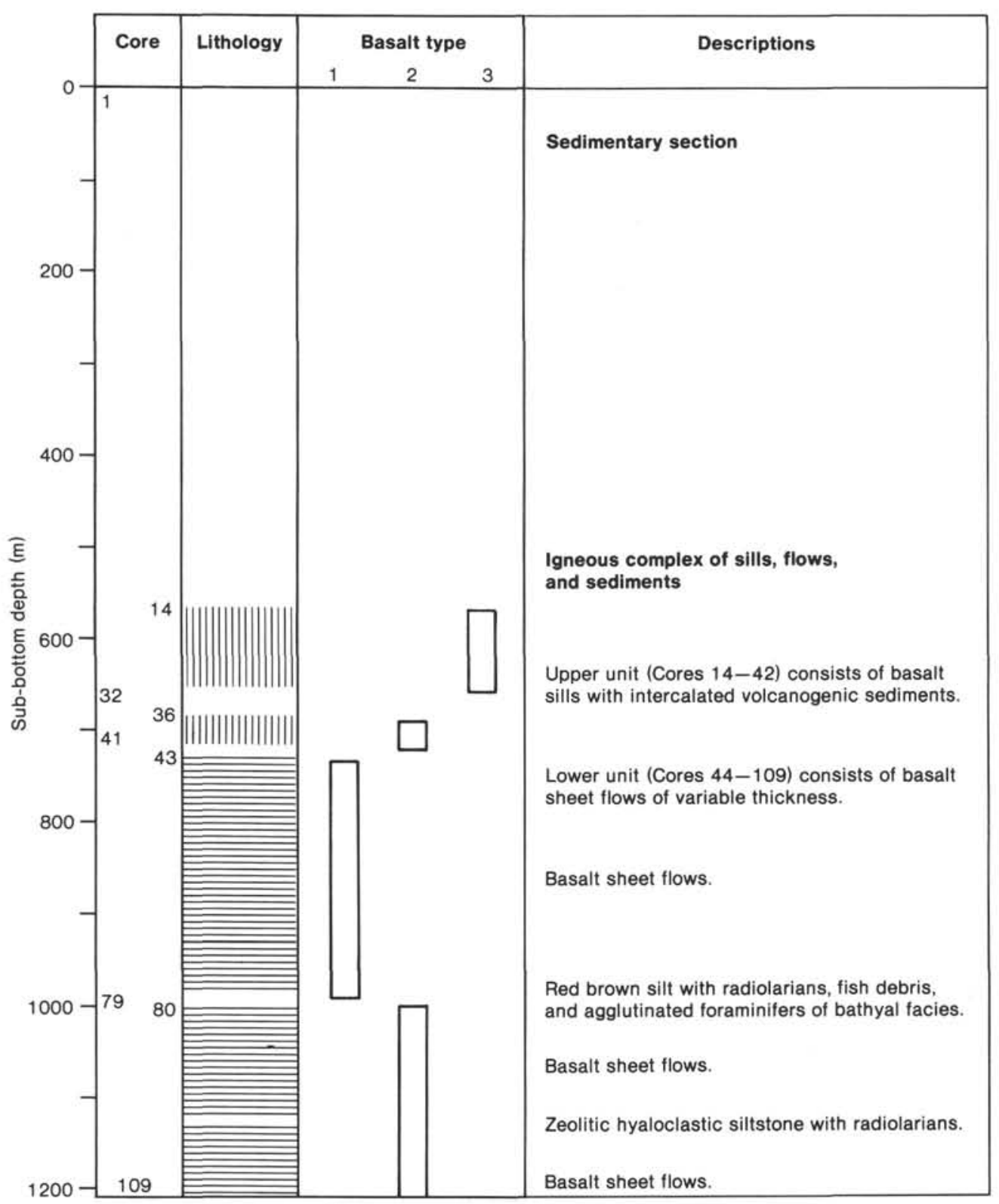

Figure 18. Generalized stratigraphic relations in the igneous complex in Hole 462A, Nauru Basin.

affected the Nauru Basin or its borders. Moreover, the carbonized terrestrial plant remains (Jenkyns and Schlanger, 1981) in the upper Aptian section indicate that some Aptian volcanoes were built above sea level.

Of the two sets of sills distinguished from each other on stratigraphic, geochemical, and paleomagnetic grounds, the upper set (above Core 462A-32) presumably is the older, because its average paleomagnetic inclinations dip south at steeper angles than those of the lower set, and the Pacific plate was moving northward. The ${ }^{40} \mathrm{Ar} /{ }^{39} \mathrm{Ar}$ ages reported by Ozima et al. (1981) are $110 \mathrm{Ma}$ for a sample from the lower sills (Core 462A-32; age relatively reliable) and $120 \mathrm{Ma}$ from the upper sills (Core 60; approximate age only). Thus the radiometric ages seem to support the sequence of the upper sill as being older than the lower sills, and they are mid-Cretaceous ages, now recognized as a time of major igneous activity in the Pacific. There is great difficulty, however, in reconciling these specific ages with the paleontological ages, namely of intruding 120 -Ma (early Barremian age), or even 110-Ma (later Aptian age), sills into sediments deposited in late Albian or Cenomanian time (Larson, Schlanger, et al., 1981; about $100 \mathrm{Ma}$ ).

There is no doubt of igneous activity in or near the Nauru basin in the late Campanian (about 75-70 Ma), a time of volcanism for so much of the Pacific. There are major volcanic components in the Campanian sedimentary section at Site 462 . At the present time we authors remain of different opinions about the time of sill injection. One of us (RM) suggests there may be moderate errors in the radiometric dating of the sills and that their time of intrusion may correspond to the Campanian volcanism. The other (SOS) suggests there are smaller errors in the radiometric dating, that the sills are of Apti- 


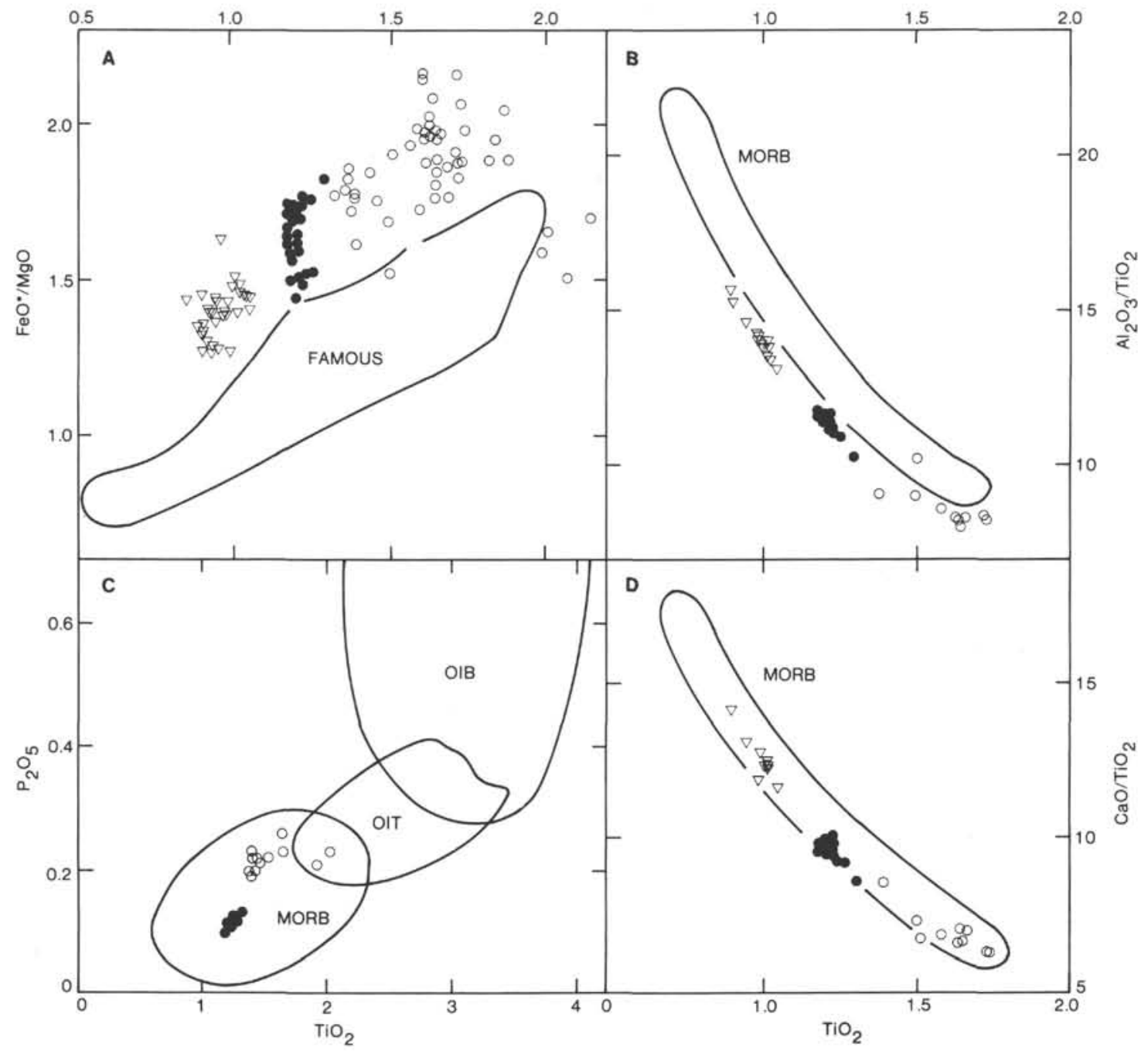

Figure 19. Major-element variation of Nauru Basin basalts relative to fields of analyses from part of the Mid-Atlantic Ridge (FAMOUS), mid-ocean ridge basalts (MORB), ocean-island basalts (OIB), and ocean-island tholeiites (OIT). (See discussion and references in Castillo et al., this volume.)

an and Albian age, and that the Campanian volcanism is a separate event.

Thus the igneous history of the Nauru Basin can be summarized as follows: (1) formation of lithosphere in the Oxfordian, about $145 \mathrm{Ma}$, along the Pacific-Phoenix spreading center; (2) eruption of an extensive and thick mass of flows from numerous small rifts during the Early Cretaceous, probably Valanginian, about 130 $\mathrm{Ma}$; (3) nearby volcanism and perhaps intrusion of sills in two episodes in mid-Cretaceous time, in the Aptian or Albian or both, about $100 \mathrm{Ma}$; and (4) nearby volcanism, and perhaps intrusion of the sills in two episodes, in the Campanian, about $75 \mathrm{Ma}$.

\section{ACKNOWLEDGMENTS}

We thank the scientists on Legs 61,62 and 89 for their interest in the sedimentary and volcanic history of the western Pacific. This is HIG Contribution Number 1653.

\section{REFERENCES}

Arthur, M. A., and Schlanger, S. O., 1979. Cretaceous "oceanic anoxic events" as causal factors in development of reef-reservoired giant oil fields. Bull. Am. Assoc. Pet. Geol., 63:870-885.
Arthur, M. A., Schlanger, S. O., and Jenkyns, H. C., in press. The Cenomanian-Turonian oceanic anoxic event, II, paleoceanographic controls on organic matter production and preservation. In Brooks, J., Fleet, S. (Eds.), Marine Petroleum Source Rocks. Geol. Soc. London Spec. Pub.

Batiza, R., 1981. Trace-element characteristics of Leg 61 basalts. In Larson, R. L., Schlanger, S. O., et al., Init. Repts. DSDP, 61: Washington (U.S. Govt. Printing Office), 689-695.

Batiza, R., Larson, R. L., Schlanger, S. O., Shcheka, S. A., and Tokuyama, H., 1980. Trace element abundances in basalts of the Nauru Basin (DSDP Leg 61): Late Cretaceous off-ridge volcanism in the western Pacific. Nature, 186:476-478.

Batiza, R., Shcheka, S., Tokuyama, H., Muehlenbachs, K., Vallier, T. L., Lee-Wong, F., Seifert, K. E., Windom, K. E., Book, P., and Fujii, N., 1981. Summary and index to petrologic and geochemical studies of Leg 61 basalts. In Larson, R. L., Schlanger, S. O., et al., Init. Repts. DSDP, 61: Washington (U.S. Govt. Printing Office), 829-839.

Berggren, W. A., and van Couvering, J. A., 1974. The late Neogene: biostratigraphy, geochronology, and paleoclimatology of the last 15 million years in marine and continental sequences. Paleogeogr. Paleoclimatol. Paleoecol., 16:1-216.

Boersma, A., and Shackleton, N., 1977. Oxygen and carbon isotope record through the Oligocene, DSDP Site 366, equatorial Atlantic. In Lancelot, Y., Seibold, E., et al., Init. Repts. DSDP, 41: Washington (U.S. Govt. Printing Office), 957-961. 
Candé, S. C., Larson, R. L., and La Brecque, J. L., 1978. Magnetic lineations in the Pacific Jurassic quiet zone. Earth Planet. Sci. Lett., 41:4343-440.

Cann, J. R., 1981. Basalts from the ocean floor. In Emiliani, C. (Ed.), The Sea (Vol. 7): New York (Wiley-Interscience), 363-390.

Chase, T. E., Menard, H. W., and Mammerickx, J., 1970. Bathymetry of the North Pacific. Scripps Inst. Oceanogr. IMR Tech. Rept. Ser., TR-12, Chart 6.

Cole, W. S., 1957. Larger foraminifera from Eniwetok drillholes. U.S. Geol. Survey Prof. Paper 260-V, pp. 741-784.

Crough, S. T., 1978. Thermal origin of mid-plate hot-spot swells. Geophys. J. R. Astron. Soc., 55:451-469.

Detrick, R. S., and Crough, S. T., 1978. Island subsidence, hotspots and lithospheric thinning. J. Geophys. Res., 83:1236-1244.

Fisher, R. V., and Schmincke, H.-U., 1984. Pyroclastic Rocks: Berlin (Springer-Verlag).

Gordon, R. G., 1982. The Late Maastrichtian palaeomagnetic pole of the Pacific plate. Geophys. J. R. Astron. Soc., 69:129-140.

1983. Late Cretaceous apparent polar wander of the Pacific Plate: evidence for a rapid shift of the Pacific hotspots with respect to the spin axis. Geophys. Res. Lett., 10:709-712.

Gordon, R. G., and Cox, A., 1980. Calculating palaeomagnetic poles for oceanic plates. Geophys. J. R. Astron. Soc., 63:619-640.

Graciansky, P. C. de, Poag, C. W., et al., 1984. Init. Repts. DSDP, 80: Washington (U.S. Govt. Printing Office).

Haak, R., and Postuma, J. A., 1975. The relation between the Tropical Planktonic Foraminiferal zonation and the Tertiary Far East Letter Classification. Geol. en Mijnbouw, 54:195.

Hardenbohl, J., and Berggren, W. A., 1978. A new Paleogene numerical time scale. In Cohie, G. V., Glassner, M. F., and Hedberg, H. D. (Eds.), Contributions to the Geologic Time Scale. Am. Assoc. Pet. Geol. Stud. Geol., 6:213-234.

Heezen, B. C., MacGregor, I. D., et al., 1973. Init. Repts. DSDP, 20: Washington (U.S. Govt. Printing Office).

Hilde, T. W. C., Uyeda, S., and Kroenke, L. W., 1977. Evolution of the Western Pacific and its margin. Tectonophysics, 38:145-165

Jenkyns, H. C., 1980. Cretaceous anoxic events: from continents to oceans. J. Geol. Soc. London, 137:171-188.

Jenkyns, H. C., and Schlanger, S. O., 1981. Significance of plant remains in redeposited Aptian sediments, Hole 462A, Nauru Basin, to Cretaceous oceanic-oxygenation models. In Larson, R. L., Schlanger, S. O., et al., Init. Repts. DSDP, 61: Washington (U.S. Govt. Printing Office), 557-562.

Keigwin, L., and Keller, G., 1984. Middle Oligocene cooling from equatorial Pacific DSDP Site 77B. Geology, 12:16.

Kennett, J. P., von der Borch, C. C., et al., in press. Init. Repts. DSDP, 90: Wasbington (U.S. Govt. Printing Office).

Kulp, J. L., 1963. Potassium-argon dating of volcanic rocks. Bull. Volcanol., 26:247-258.

Ladd, H. S., Ingerson, E., Townsend, R. C., Russell, M., and Stephenson, H. K., 1953. Drilling on Eniwetok Atoll, Marshall Islands. Bull. Am. Assoc. Pet. Geol., 37:2257.

Lancelot, Y., 1978. Relations entre évolutions sédimentaire et tectonique de la plaque Pacifique depuis le Crétacé inférieur. Mem. Soc. Geol. France., 134.

Larson, R. L., and Schlanger, S. O., 1981. Cretaceous volcanism and Jurassic magnetic anomalies in the Nauru Basin, western Pacific Ocean. Geology, 9:480-484.

Larson, R. L., Schlanger, S. O., et al., 1981. Init. Repts. DSDP, 61: Washington (U.S. Govt. Printing Office).

McNutt, M., and Menard, H. W., 1978. Lithospheric flexure and uplifted atolls. J. Geophys. Res., 83:1206-1212.

Menard, H. W., 1964. Marine Geology of the Pacific: New York (McGraw-Hill).

1973. Depth anomalies and the bobbing motion of drifting islands. J. Geophys. Res., 78:5128-5137.

Miller, K. G., Curry, W. B., and Ostermann, D. R., 1984. Late Paleogene (Eocene to Oligocene) benthic foraminiferal oceanography of the Goban Spur region, Deep Sea Drilling Project Leg 80. In Graciansky, P. C. de, Poag, C. W., et al., Init. Repts. DSDP, 80: Washington (U.S. Govt. Printing Office), 505-538.

Miller, K. G., Mountain, G. S., and Tucholke, B. E., 1985. Oligocene glacio-eustasy and erosion on the margins of the North Atlantic. Geology, 13:10.
Moberly, R., and Jenkyns, H. C., 1981. Cretaceous volcanogenic sediments of the Nauru Basin, Deep Sea Drilling Project Leg 61. In Larson, R. L., Schlanger, S. O., et al., Init. Repts. DSDP, 61: Washington (U.S. Govt. Printing Office), 533-548.

Olsson, R. K., Miller, K. G., and Ungrady, T. E., 1980. Late Oligocene transgression of middle Atlantic coastal plain. Geology, 8: 549.

Ozima, M., Saito, K., and Takigami, Y., 1981. ${ }^{40} \mathrm{Ar}^{-39} \mathrm{Ar}$ geochronological studies on rocks drilled at Holes 462 and 462A, Deep Sea Drilling Project Leg 61. In Larson, R. L., Schlanger, S. O., et al., Init. Repts. DSDP, 61: Washington (U.S. Govt. Printing Office), 701-703.

Parsons, B., and Sclater, J. G., 1977. An analysis of the variation of ocean floor bathymetry and heat flow with age. J. Geophys. Res., 82:803-827.

Poag, C. W., 1980. Foraminiferal stratigraphy, paleoenvironments, and depositional cycles in the outer Baltimore Canyon Trough. In Scholle, P. A. (Ed.), Geological Studies of the COST No. B-3 well, United States Mid-Atlantic Slope Area. U.S. Geological Survey Circular 833, pp. 44-65.

Pollack, H. N., Gass, I. G., Thorpe, R. S., and Chapman, D. S., 1981. On the vulnerability of lithospheric plates to mid-plate volcanism: reply to comments by P. R. Vogt. J. Geophys.Res., 86: 961-966.

Premoli Silva, I., and Brusa, C., 1981. Shallow-water skeletal debris and larger foraminifers from Deep Sea Drilling Project Site 462, Nauru Basin, Western Equatorial Pacific. In Larson, R. L., Schlanger, S. O., et al., Init. Repts. DSDP, 61: Washington (U.S. Govt. Printing Office), 439-474.

Savin, S., Douglas, R. G., and Stehli, F. G., 1975. Tertiary marine paleotemperatures. Bull. Geol. Soc. Am., 86:1499-1510.

Schlanger, S. O., 1963. Subsurface geology of Eniwetok atoll. U.S. Geol. Survey Prof. Paper 260-BB, pp. 901-1066.

Schlanger, S. O., in press. High-frequency sea level oscillations in the Cretaceous: an emerging geophysical problem. In Hsü, K. J. (Ed.), History of Mesozoic and Cenozoic Oceans. Am. Geophys. Union Monograph.

Schlanger, S. O., Arthur, M. S., Jenkyns, H. C., and Scholle, P. A., in press. The Cenomanian-Turonian oceanic anoxic event, I, stratigraphy and distribution of carbon-rich beds and the marine $\delta^{13} \mathrm{C}$ excursion. In Brooks, J., and Fleet, S. (Eds.), Marine Petroleum Source Rocks. Geol. Soc. London Spec. Pub.

Schlanger, S. O., Jackson, E. D., et al., 1976. Init. Repts. DSDP, 33: Washington (U.S. Govt. Printing Office).

Schlanger, S. O., and Jenkyns, H. C., 1976. Cretaceous oceanic anoxic events: causes and consequences. Geol. en Mijnbouw, 55:179184.

Schlanger, S. O., Jenkyns, H. C., and Premoli Silva, I., 1981. Volcanism and vertical tectonics in the Pacific Basin related to global Cretaceous transgressions. Earth Planet. Sci. Lett., 52:435-449.

Schlanger, S. O., and Premoli Silva, I., 1981. Tectonic, volcanic, and paleogeographic implications of redeposited reef fauna of Late Cretaceous and Tertiary age from the Nauru Basin and the Line Islands. In Larson, R. L., Schlanger, S. O., et al., Init. Repts. DSDP, 61: Washington (U.S. Govt. Printing Office), 817-828.

, in press. Oligocene sea level falls recorded in mid-Pacific atoll and archipelagic apron settings. Geology.

Shipley, T. H., Whitman, J. M., Duennebier, F. K., and Petersen, L. D., 1983. Seismic stratigraphy and sedimentation history of the East Mariana Basin, western Pacific. Earth Planet. Sci. Lett., 64: 257-275.

Steiner, M. B., 1981a. Paleomagnetism of the Cretaceous section, Site 462. In Larson, R. L., Schlanger, S. O., et al. Init. Repts. DSDP, 61: Washington (U.S. Govt. Printing Office), 711-716.

1981b. Paleomagnetism of the igneous complex, Site 462 . In Larson, R. L., Schlanger, S. O., et al., Init. Repts. DSDP, 61: Washington (U.S. Govt. Printing Office), 717-729.

Vail, P. R., and Hardenbohl, J., 1979. Sea level change during the Tertiary. Oceanus, 22:71.

Vail, P. R., Mitchum, R. M., Jr., Todd, R. G., Widmier, J. M., Thompson, S., III, Sangree, J. B., Bubb, J. N., and Hatelid, W. G., 1977. Seismic stratigraphy and global changes in sea level. In Payton, C. E. (Ed.), Seismic Stratigraphy-Applications to Hydrocarbon Exploration. Am. Assoc. Pet. Geol. Mem., 26:49-212. 
van Hinte, J. E., 1976a. A Cretaceous time scale. Bull. Am. Assoc. Pet. Geol., 60:498-516.

van Hinte, J. E., 1976b. A Jurassic time scale. Bull. Am. Assoc. Pet. Geol., 60:489-497.

Whitman, J. M., 1981. Tectonic and bathymetric evolution of the Pacific Ocean since $74 \mathrm{Ma}$ [Master's dissert.]. University of Miami, Florida.
Winterer, E. L., Ewing, J., et al., 1973. Init. Repts. DSDP, 17: Washington (U.S. Govt. Printing Office).

Date of Initial Receipt: 15 October 1985 Date of Acceptance: 15 October 1985
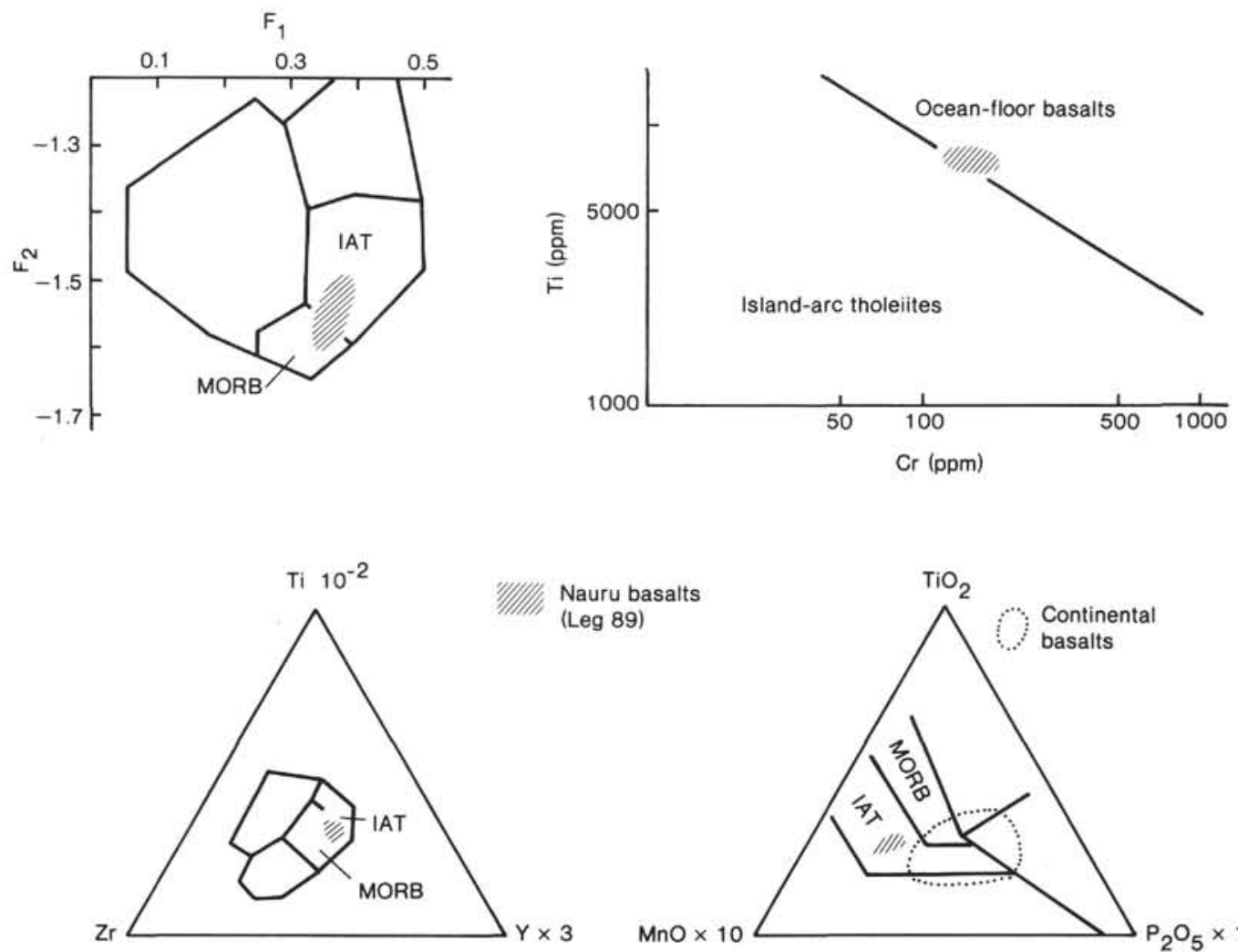

Nauru basalts

(Leg 89)
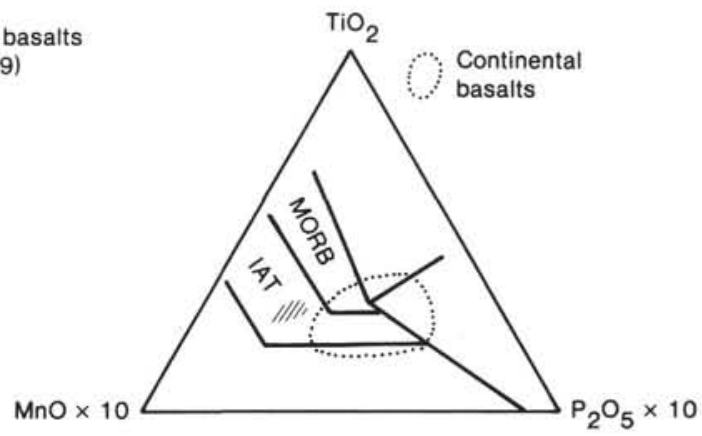

Figure 20. Distribution of Hole $462 \mathrm{~A}$ basalt analyses on various tectonic discrimination diagrams. There is no geomorphic or geophysical evidence, however, to suggest that an island arc occupied the Nauru basin in the Cretaceous. (Diagrams referenced in Floyd, this volume.) 